\title{
THE SEARCH FOR MEANING: CONTINUING PROBLEMS WITH THE INTERPRETATION OF TREATIES
}

\author{
Peter McRae
}

This paper argues that old controversies regarding the objects and methods of treaty interpretation have not been resolved by the coming into force of articles 31 and 32 of the Vienna Convention on the Law of Treaties 1969. The articles, it is argued, have not so much resolved previous debates between "schools" of interpretation, as obscured them under an apparently clear regime, while interpreters continue to adopt their own preferences. The paper describes the three main schools - textualist, intentions of the parties, and teleological - and concludes none offers a satisfactory scheme by itself. It then examines the development of the Convention articles, and concludes they represented a compromise in which the drafters failed to resolve the key issue of the underlying purpose or object of interpretation. It then shows that an orthodox interpretation of the articles has developed, which assumes they embody the textualist position. The paper then discusses how this orthodoxy has been accepted by the majority of the International Court of Justice in the 1990s, but with significant dissent drawing on insights from especially an intentions of the parties approach. The paper then draws on insights from modern approaches to the interpretation of commercial contracts, to suggest that the best resolution of the "text versus intentions" dichotomy lies in accepting that establishing the actual intentions of parties is the purpose of interpretation, and that therefore an apparently clear text will be strong but not conclusive evidence of such intentions. The paper examines how this refinement would have helped to resolve difficult interpretations before the ICJ, and concludes that such an approach is both desirable and consistent with articles 31 and 32 .

\section{INTRODUCTION}

It might seem that controversy and uncertainty over the interpretation of treaties, which once provoked heated debates, into which even great legal writers ventured

\footnotetext{
* Submitted for LLB(Hons) degree.
} 
uneasily, ${ }^{1}$ have now been dissipated. Old doctrinal controversies on both the purposes and methods of interpretation have apparently been resolved by the codification of the law in articles 31 and 32 of the Vienna Convention on the Law of Treaties (the Vienna Convention). ${ }^{2}$ Even more importantly, the articles have repeatedly been accepted as reflecting customary international law. ${ }^{3}$ Given their deliberately non-detailed nature, ${ }^{4}$ the articles will not by themselves resolve every difficult interpretation; they do however appear to give us a clear regime within which to work to achieve resolution.

It is submitted that in reality the controversies have not gone away. Recent decisions of the International Court of Justice (ICJ) show that the Court still tends to divide on interpretation issues. This essay will argue in part that at least some of the division is traceable back to the old controversies about methods and, especially, purposes. Overall it is better to suggest that articles 31 and 32 have temporarily obscured a debate, not resolved it. If any real consensus is to be achieved on the purpose of and correct approach to treaty interpretation, articles 31 and 32 will require re-examination, leading to a better appreciation of how they should be applied.

The essay will examine the original controversy of the "schools": The "textual", the "intentions of the parties", and the "teleological" schools. Writers who have offered their own variants will also be considered. The analysis will show that differences in approach arise not just from differences over the value of advocated methods, but rather from quite different conceptions of basic purpose - not just "how", but also "why" we interpret treaties.

The history of articles 31 and 32 is then analysed, especially the International Law Commission's (ILC) work. After examination of how the articles were viewed in the 20 years after the Vienna Convention, I will then examine two ICJ cases from the 1990's which considered the articles, and treaty interpretation generally.

1 Sir I Sinclair The Vienna Convention on the Law of Treaties (2 ed, Manchester University Press, Manchester, 1984) 114; Lord McNair The Law of Treaties (2 ed, Oxford University Press, Oxford, 1961) 364 .

2 Vienna Convention on the Law of Treaties (22 May 1969) UNTS 1155 331. [Vienna Convention]

3 Case Concerning the Territorial Dispute (Libyan Arab Jamahiriya/Chad) [1994] ICJ 6, 21-22, para 41 [Libya v Chad]; Case Concerning Maritime Delimitation and Territorial Questions Between Qatar and Bahrain (Jurisdiction and Admissibility) [1995] ICJ 6, 18, para 33 [Qatar v Bahrain]; Case concerning Kasikili/Sedudu Island (Botswana/Namibia) [1999] ICJ 6, para 21, <www.icjcij.org/cijwww/cij/ccases/cbona/cbonabanner.htm> (last accessed 24 May 2001) [Kasikili Island].

4 See Report of the International Law Commission on Draft Articles (1966) II YBILC 169, 218 para 5. [ILC Commentary 1966] 
As suggested above, this will show that while there has been the appearance of an agreed position, based on a "clear" meaning of the articles, there is no real consensus on either role or purpose, or methodology. While there is a dominant view, based on one reading of articles 31 and 32, emphasising "primacy of the text", 5 others, while paying lipservice to the articles' customary laws status, find it necessary and possible to resort to a different approach reminiscent of the intentions school. It is submitted that this continuing divergence points to real inadequacies in the orthodox position, which need to be resolved if there is to be any real clarity on the law. Equally, a simple switch to an "intentions" approach is likely to be similarly inadequate. It is necessary to look for a satisfactory synthesis, consistent with articles 31 and 32, which can lead to more consistently satisfactory interpretations in practice.

Given the persistent differences, a complete resolution may not be possible. However it is suggested that insight can be gained from reference to developments in the modern law of contract interpretation. These emerging approaches, themselves still controversial, will help to put the claims of the various schools in perspective, and suggest how they may work together more satisfactorily. Articles 31 and 32 are flexible enough, interpreted appropriately, to allow this "modern contract" approach, and this approach is more likely to lead to appropriate interpretation in practice.

\section{BACKGROUND TO THE CONTROVERSY}

Modern writers accept that there have traditionally been three main "schools" in debates regarding the purpose of treaty interpretation. ${ }^{6}$ These are the textual or "ordinary or plain meaning" school, the "intentions of the parties" school, and the "purpose" or "teleological" school. Other variations exist: McDougall and other Yale scholars appear to combine elements of intentions and teleology in an approach based on the "genuine shared expectations" of the parties, ${ }^{7}$ while others espouse a "contextual" approach, ${ }^{8}$ which can be seen as either a derivative of the textual approach, or an attempt at synthesis of all three

5 See Third Report of the Special Rapporteur on the Law of Treaties to the ILC (1964) YBILC II 5, 52, phrase used by Sir H Waldock [Waldock Third Report]; compare Libya v Chad, above, 22, para 41: "Interpretation must be based above all on the text of the treaty".

6 D J Harris Cases and Materials on International Law (5 ed, Sweet \& Maxwell, London 1998) 810-811, quoting from G G Fitzmaurice; A Aust Modern treaty law and practice (Cambridge, Cambridge University Press, 2000) 184.

7 M S McDougall, H D Lasswell and J C Miller The Interpretation of International Agreements and World Public Order: Principles of Content and Procedure (New Haven Press, New Haven, 1994 Reissue with additions). See especially, Introduction to the Reissue, xxiii-lxxviii.

8 Lord McNair The Law of Treaties (2 ed, Oxford University Press, Oxford, 1961) 365; see also ILC Proceedings (1964) I YBILC 195, para 27, Mr Reuter. 
main schools. Yambrusic argues for the need to search for "objective intentions", 9 and Stone argued that there are in fact no rules, but only fictions which act as a smokescreen for judicial creativeness. ${ }^{10}$ Given this variety, it is necessary to critically examine the schools, to assess their relative claims.

\section{A The Textual Approach}

This approach starts from a presumption that words will normally have an ordinary meaning, which is either self-evident, or is readily established by textual analysis. It is therefore possible to reduce agreements to clear language, and there should rarely be any need to "go behind" that to seek deeper intentions. ${ }^{11}$ We should presume that the intentions of the parties are reflected in the words they have used, and the treaty text becomes "sauf de rares exceptions, la seule et la plus récente expression de la volunté commune des parties". ${ }^{12}$ Therefore the primary goal of interpretation is to ascertain the meaning of the text. ${ }^{13}$ This implies a reluctance to examine materials extrinsic to the treaty, as it is the words that matter. It is the "intentions of the treaty", not of the parties, that we are to elucidate. ${ }^{14}$

This approach is of ancient pedigree, and can be seen to draw authority from Vattel, who famously stated: "[t]he prime general maxim of interpretation is that it is not permissible to interpret that which has no need of interpretation" ${ }^{15}$ While Sinclair suggests that this merely states the result of a process of interpretation, rather than a principle of interpretation itself, this is not obvious from the words themselves, and Haraszti points out

9 E S Yambrusic Treaty Interpretation Theory and Reality (UPA, Lanham (Maryland), 1987) 249-251.

10 J Stone "Fictional elements in treaty interpretation" (1955) 1 Sydney Law Review 344-368.

11 G G Fitzmaurice "Vae Victis or Woe to the Negotiators! Your Treaty or Our 'Interpretation' of it" (1971) 65 AJIL 358, 363. [Fitzmaurice 1971]

12 Comment of M Huber (1952) 44 Annuaire de l'Institut de droit international 199 [Annuaire]; quoted by Sir H Waldock in the Third Report of the Special Rapporteur on the Law of Treaties to the ILC (1964) YBILC II 5, 56, para 13.

13 Sir I Sinclair The Vienna Convention on the Law of Treaties (2 ed, Manchester University Press, Manchester, 1984), 115, summarising G G Fitzmaurice "The Law and Procedure of the International Court of Justice, 1951-4: Treaty Interpretation and other Treaty Points" (1957) 33 BYIL 203, 204-7. [Fitzmaurice 1957]

14 Fitzmaurice 1971, above.

15 E de Vattel Le droit des gens ou principes de la loi naturelle, appliqués à la conduite et aux affaires des Nations et des Souverains Livre II, chapter XVII, quoted in G Haraszti Some Fundamental Problems of the Law of Treaties (Akademiai Kiado, Budapest, 1973) 91-92. The full quotation continues: " Quand une Acte est conçu en termes clairs et précis, quand le sens en est manifeste et ne conduit à rien d'absurde : on n'a aucune raison de se refuser au sens que cet Acte présente naturellement. » 
that both the ICJ and its predecessor have frequently relied by implication on Vattel to prohibit recourse to extrinsic aids, where a treaty was "sufficiently clear", and absent absurdity. ${ }^{16}$ Vattel therefore propounded and the courts often accepted a "plain meaning rule" of interpretation.

A well-developed expression of this approach is given by Sir Gerald Fitzmaurice. Arguing from his analysis of the World Court, ${ }^{17}$ Fitzmaurice enunciated six principles of interpretation. The first three, especially I, Principle of actuality (or textuality) and II, Principle of the natural and ordinary meaning, encapsulate a mandatory textualist approach. ${ }^{18}$ Nothing should get in the way of the "natural" or "ordinary" meaning, if it is "clear", and the interpreter need not and in theory cannot look any further if there is a clear reading. It is presumed that this clear reading must be giving effect to what the parties intended.

\section{Critique}

The textual approach has usually been accepted as the majority or orthodox position, ${ }^{19}$ and it is not difficult to see why. A textual approach is easy to understand and relatively easy to execute. The assumption that parties can generally be taken to mean what they say seems reasonable. ${ }^{20}$ Interpreters can make use of a simple reading, supplemented where necessary by more sophisticated logical tools, including judicious application of maxims such as a contrario or ejusdem generis, without having to turn these into legal rules. ${ }^{21}$ There will normally be neither need nor permission to turn to more wide-ranging but more complicated sources, such as preparatory works, as the presumption is that most texts will be explicable, and the meaning of the text is all that is required. Interpreters can limit excursions to the "rare exceptions" anticipated by Huber. ${ }^{22}$

This does tend to look like an argument of convenience or expediency - we should limit ourselves to a textual approach, as it is simpler and cheaper. Jacobs has however

16 Haraszti, above, 92-93. Relevant cases include the Lotus case PCIJ Ser A 10, 16; the Admissions case, [1948] ICJ 63; and the Competence case [1950] ICJ 227.

17 Both the ICJ and its predecessor the Permanent Court of International Justice (PCIJ).

18 Fitzmaurice 1957, above, 205.

19 See Sir H Waldock Third Report of the Special Rapporteur on the Law of Treaties to the ILC (1964) YBILC II 5, 54, refers to "the majority of modern writers".

20 See G G Fitzmaurice "Vae Victis or Woe to the Negotiators! Your Treaty or Our 'Interpretation' of it" (1971) 65 AJIL 358, 363.

21 See G Haraszti Some Fundamental Problems of the Law of Treaties (Akademiai Kiado, Budapest, 1973) 110-111 for discussion of the place of the logical principles, albeit from the standpoint of an advocate of an intentions approach.

22 See M Huber (1952) 44 Annuaire de l'Institut de droit international 199. 
argued that the textual approach can be justified on grounds of principle and policy. ${ }^{23}$ The real problem for an ordinary meaning approach however is that words are rarely or never sufficiently or consistently clear. McLauchlan has argued convincingly that it is not possible to say that words have a "fixed", or a "plain" meaning or a "proper signification", independent either of the writer or reader. ${ }^{24}$ Like Lauterpacht, ${ }^{25}$ he refers to Oliver $\mathrm{W}$ Holmes: ${ }^{26}$

A word is not a crystal, transparent and unchangeable, it is a skin of a living thought and may vary in colour and content according to the circumstances and the time it is used.

In treaties, even more so than in other formal documents, there is almost inevitably ambiguity, shades of meaning, and room for differing views. This comes in part from treaties frequently being plurilingual, and also they are, even more than contracts, often the results of difficult negotiations between parties with widely differing interests, where things may be deliberately left unsaid for political or diplomatic reasons, or where an ambiguous formula allows several parties to each feel they have achieved their objectives. Lauterpacht quotes the Treaty of Lausanne 1924 as one example. ${ }^{27}$ Qatar $v$ Bahrain is a modern case, where the words allowed both sides to think they had got what they wanted. ${ }^{28}$

This prevalence, even "natural" occurrence of ambiguity means it is possible for several different interpreters to conclude they have arrived at the single, clear and ordinary meaning of a term, while in fact coming to different or opposite meanings. ${ }^{29}$ This not only undermines the effectiveness of a textual approach, as it does not satisfactorily resolve anything, but it also suggests that it will often be only a smokescreen or post facto

23 F Jacobs "Varieties of Approach to Treaty Interpretation: with Special Reference to the Draft Convention on the Law of Treaties Before the Vienna Diplomatic Conference" (1969) 18 ICLQ 318, 342.

24 D McLauchlan "The Plain Meaning Rule of Contract Interpretation" (1996) 2 NZBLQ 80, 84.

$25 \mathrm{H}$ Lauterpacht "Restrictive Interpretations and the Principle of Effectiveness in the Interpretation of Treaties" (1949) 26 BYIL 48, 53. [Lauterpacht 1949]

Towne v Eisner (1918) 245 US 418, 425; McLauchlan, above, 85.

27 Lauterpacht 1949, above, 77-78.

28 Qatar v Bahrain [1995] ICJ 6, 18; see discussion below in part V.

29 See G Haraszti Some Fundamental Problems of the Law of Treaties (Akademiai Kiado, Budapest, 1973) 93-94, shows that in both the Competence and Asylum cases, different members of the Court came to opposite meanings for disputed terms, each holding that any other meaning was "inconceivable" as the meaning was "clear". 
justification for a decision which an interpreter reaches by other means. ${ }^{30} \mathrm{~A}$ textual approach can be both arbitrary and uncertain, casting significant doubt on its ability to deliver the advantages argued for it.

\section{Variations}

Some would argue that textualism is never as rigid as it appears in theory. The approach accepts that documents will sometimes be ambiguous, necessitating a wider range of tools - it merely suggests ambiguity is less prevalent or likely than others consider. In any case, what is being set out in Fitzmaurice's principles, even arguably in articles 31 and 32, is a contextual approach, not a rigid textual one. ${ }^{31}$ Words only have meaning in their context, and this is clearly allowed for in Fitzmaurice's principle III. ${ }^{32}$ This approach is embodied in the 1956 Resolution of the Institute of International Law, ${ }^{33}$ and is also at the heart of McNair's synthesis. ${ }^{34}$

The problem with context is how wide should it be. To the textualist, it will merely be the words or the text in their context, no broader than the treaty itself, whereas McNair envisages something wider, and proponents of intentions or teleology will not see any reasons to limit it at all. If the contextual approach is no more than a more nuanced version of the textual, then it will still be interested in revealing only the meaning of the text, and will be subject to the same criticisms. If its purposes are in fact broader, then it may be better placed under one of the other schools, or may in fact be a genuine synthesis. The question of possible syntheses will be returned to in section VI.

30 See Lauterpacht 1949, above, 53-55, especially his discussion of the resolution of interpretation issues in Corfu Channel Merits [1949] ICJ 24.

31 F Jacobs "Varieties of Approach to Treaty Interpretation: with Special Reference to the Draft Convention on the Law of Treaties Before the Vienna Diplomatic Conference" (1969) 18 ICLQ 318, 334-335.

32 G G Fitzmaurice "The Law and Procedure of the International Court of Justice, 1951-4: Treaty Interpretation and other Treaty Points" (1957) 33 BYIL 203, 205.

33 Quoted in Sir H Waldock Third Report of the Special Rapporteur on the Law of Treaties to the ILC (1964) YBILC II 5, 55.

34 Lord McNair The Law of Treaties (2 ed, Oxford University Press, Oxford, 1961) 365: Tribunals are to give effect to "[the parties'] intention as expressed in the words used by them in the light of the surrounding circumstances". 


\section{B The Intentions of the Parties}

For the "intentions" school, the primary or only goal of interpretation is to establish the intention of the parties, so it can be given effect. ${ }^{35}$ As Hersch Lauterpacht, the most notable proponent of this approach put it: ${ }^{36}$

It is the duty of the judge to resort to all available means - including rules of construction - to discover the intentions of the parties; to avoid using rules of interpretation as a ready substitute for active and independent search for intention; and to refrain from neglecting any possible clues, however troublesome may be their examination and however liable they may be to abuse, which may reveal or render clear the intention of the authors of the rule to be interpreted.

Several points emerge. First, the disagreements between the schools are about more than method. The debate is about the purpose or object of treaty interpretation, not just allowable or preferable techniques. Secondly, the position we take on purpose affects the approach to methods. As the intentions school is unwilling to ascribe a life or meaning of its own to text, it more easily accepts that no possible tool for interpretation, which might reveal actual intentions, should be excluded. The intentions school will usually begin with text, but look also to context, broadly defined, consider evidence contained in preparatory works or other sources, use supposed "rules" such as a contrario as a guide or aid where useful, and examine the subsequent conduct of the parties as evidence of intentions. Thirdly, there is at least some distinction between the act of interpretation and that of application, even though one follows the other. ${ }^{37}$ By contrast, for the textualist, if interpretation is achieved by ascertaining the ordinary meaning, then there is arguably no separate process of application, as the application proceeds naturally from the clarified ordinary meaning.

While the intentions school denies Huber's contention that the words of the text are the authentic expression of the will of the parties - and therefore all that need be explained the position does not deny an important place to text. In proposed draft articles for the ILI,

35 See Sir I Sinclair The Vienna Convention on the Law of Treaties (2 ed, Manchester University Press, Manchester, 1984) 114.

$36 \mathrm{H}$ Lauterpacht "Restrictive Interpretations and the Principle of Effectiveness in the Interpretation of Treaties" (1949) 26 BYIL 48, 83.

37 See G Haraszti Some Fundamental Problems of the Law of Treaties (Akademiai Kiado, Budapest, 1973) 29 on the difference between interpretation and the act of application to a particular case. 
Lauterpacht made it clear it was necessary to: "prendre le sens naturel des termes comme point de départ du processus d'interprétation". 38

While it has been argued that Lauterpacht's inclusion of the text as a starting point was probably a negotiating concession to textualists, the intentions school does recognise the weight an apparently unambiguous text carries. It merely does not accept it as decisive, given the different conception of the underlying purpose. If in a particular case there is better and contradicting evidence, it cannot be ignored.

\section{Critique}

On one level the intentions approach is hard to argue with. It is easy to see that the underlying object is a purer version than that aimed at by the textual approach: one is looking for actual common intentions, rather than merely presuming that some of the words used are the only possible expression of common will. This suggests an intentions approach is more likely to give effect to good faith and the basic imperative of pacta sunt servanda. ${ }^{39}$ It is treaties which must be given effect to in good faith, not merely words. On an equally fundamental level, it can be argued that an intentions approach is required by the consensual basis of international law: ${ }^{40}$ Intentions, rather than presumed intentions based on an expression, must be preferable.

There are of course immediate objections to this apparent superiority. Firstly it is significant that it is often referred to as the "subjective" school, often by Anglo-Saxon commentators. ${ }^{41}$ There is an inherent distrust of the subjective as ultimately unknowable, uncertain and therefore unattainable. It is significant that Sinclair ${ }^{42}$ contrasts the subjective school with the textual or "objective": That which is objective is surely more likely to provide stronger evidence and better analysis.

38 H Lauterpacht (1950) 43 Annuaire de l'Institut de droit international 433. Principle 2 enshrines widest possible resort to preparatory works, even where the words are "clear" but contested.

39 Vienna Convention, Article 26.

40 F Jacobs "Varieties of Approach to Treaty Interpretation: with Special Reference to the Draft Convention on the Law of Treaties Before the Vienna Diplomatic Conference" (1969) 18 ICLQ 318, 321 , also makes this point.

41 See for instance G G Fitzmaurice "The Law and Procedure of the International Court of Justice: Treaty Interpretation and Certain other Treaty Points" (1951) BYIL 1; See Sir I Sinclair The Vienna Convention on the Law of Treaties (2 ed, Manchester University Press, Manchester, 1984) 114-115; Jacobs, above, 320-322, and throughout.

42 Sinclair, above, 115. 
Linked to the suspicion of subjectivity is the apparent uncertainty of many of the proposed sources. Preparatory works are likely to support both sides of an argument, ${ }^{43}$ and may be misleading or incomplete. ${ }^{44}$ Similar or greater difficulties attach to other extrinsic sources, such as the circumstances of the conclusion of a treaty. The intentions approach may be impossible of appropriate application.

These objections are not in fact the most damaging to the intentions approach. "Subjective" is no more than a label, and it would be equally accurate to refer to an enquiry into parties' "actual" rather than "subjective" intentions. Evidence provided in an analysis of intentions should be subject to tests of reliability, and it has already been shown above that the text is not necessarily certain either. Finally, the reality is that preparatory works will be referred to almost routinely. ${ }^{45}$ Whether the text or other sources provide the most conclusive evidence of intentions and therefore meaning will vary between cases, and should not be arbitrarily restricted.

The more difficult criticism is that common intention is often illusory. While the critics point this out, ${ }^{46}$ Lauterpacht himself is alert to the issue, listing five discrete cases where there will be no actual common intention. ${ }^{47}$

While the principle of good faith may deal with some of these categories, ${ }^{48}$ Lauterpacht advocates in the end for such cases a process of analysis, considering all the circumstances including what can be said of common intentions that do or did exist, and the treaty purpose, to arrive at an "effective", "assumed" or "imputed" intention. ${ }^{49}$ Lauterpacht

43 H Lauterpacht (1950) 43 Annuaire de l'Institut de droit international 433, Sir Eric Beckett; and Jacobs, above, 339.

44 Report of the International Law Commission on Draft Articles (1966) II YBILC 20, 51. [ILC Commentary 1966]

45 ILC Commentary 1966, above, 223.

46 G G Fitzmaurice "The Law and Procedure of the International Court of Justice: Treaty Interpretation and Certain other Treaty Points" (1951) BYIL 1; H Lauterpacht (1950) 43 Annuaire de l'Institut de droit international 433, 435-444; and J Stone, "Fictional Elements in Treaty Interpretation" 1 Sydney Law Review (1955) 344, 347-350.

$47 \mathrm{H}$ Lauterpacht "Restrictive Interpretations and the Principle of Effectiveness in the Interpretation of Treaties" (1949) 26 BYIL 48, 76-82. The different categories include: Where the parties each unknowingly attribute different meanings to the same words; where one party is aware of the other's misapprehension of what has been included, and hopes to benefit from the ambiguity; where the parties use an ambiguous or non-committal expression to deal with a point of disagreement; where the parties gave no thought to the actual situation which later arises; and where different provisions of the same treaty are mutually contradictory.

48 See for instance Lauterpacht 1949 , above, 77 on the ambiguity by design problem. 
considers this will be "no mere fiction", 50 but Stone ${ }^{51}$ certainly and textualists probably would not agree. In the end, the intentions school runs into the same limitation as textualism: it will often be based on presumptions not only impossible of proof but actually untrue. In the case of intentions it arguably undercuts the very purpose the school aims at.

It is not necessary to agree with Jacobs, that Lauterpacht's difficulty leads him into teleology. ${ }^{52}$ Lauterpacht relies so far as possible on whatever actual common intention is available, and limits the application of the principle of effectiveness, or effective interpretation, to what the parties intended: the parties may have intended the treaty to be less than fully effective over the potential subject matter and range of objects of their treaty. ${ }^{53}$ Even so, given that Lauterpacht concedes there will be many occasions where there is no common intention, ${ }^{54}$ it is clear that the intentions approach cannot be a complete system of interpretation. There is therefore room for frequent controversy about whether any particular situation falls within one of the five categories, or is amenable to resolution by an intentions analysis, and the method may be guilty of muddying waters it seeks to clarify. Lauterpacht felt able, even compelled, to fill gaps in intentions, as signed treaties are part of international law, which allows no gaps. ${ }^{55}$ However he therefore would presume or imply intention, which he himself argued predicates that intention does not matter. ${ }^{56}$ It must be accepted that the fully developed scheme of the intentions approach is simply too optimistic in its claims.

\section{Variations}

An intentions-based approach is important to some writers who are not adherents of the school. Yambrusic considers that interpretation is a "complex intellectual exercise". ${ }^{57}$ Where however only apparent or objective intention can ever be found, as "the content of the

50 Lauterpacht 1949, above, 79.

51 J Stone, "Fictional elements in treaty interpretation" 1 Sydney Law Review (1955) 344, 348.

52 F Jacobs "Varieties of Approach to Treaty Interpretation: with Special Reference to the Draft Convention on the Law of Treaties Before the Vienna Diplomatic Conference" (1969) 18 ICLQ 318, 321.

53 Lauterpacht 1949, above, 74.

54 Lauterpacht 1949, above, 76.

55 Lauterpacht 1949, above.

56 Lauterpacht 1949, above, 75.

57 E S Yambrusic Treaty Interpretation Theory and Reality (UPA, Lanham MD, 1987) 250. 
individual wills is always heterogeneous". ${ }^{58}$ Intention is always a construct, even if it is "objectively" obtained from words and circumstances.

This thesis seems unnecessarily pessimistic. Taken to its logical conclusion, it in fact denies the consensual basis of international law. In the end, while Yambrusic clearly considers the textual approach inadequate on its own, the denial of actual intentions essentially limits the product of interpretation to a construct in the mind of the interpreter.

By contrast, McDougall, Lasswell and Miller (McDougal) start from thoroughgoing acceptance of the importance of subjective intentions. After positing a complex communications theory with few if any interactions or influences out of the mix, ${ }^{59}$ McDougal argues that the "primary aim" of interpretation is to "discover the shared expectations that the parties to the relevant communication have succeeded in creating in each other". ${ }^{60}$ The interpreter is not limited by any over-reliance on any particular text, but must effectively reconstruct the whole series of dealings to determine what the parties did or did not succeed in achieving. ${ }^{61}$ This leads to what Jacobs has described as an American "inclusive" approach to interpretation, where no source is excluded, and none takes precedence, except based on the evidence of the specific case. ${ }^{62}$

This looks like intentions, allied to modern communications theory. However the theory does not stop there, and McDougal defines an explicitly separate application phase which must be conducted once the shared subjectivity has been established. Of course, adherents of an intentions approach will often also point out that application is a separate and subsequent process, ${ }^{63}$ but for McDougall it takes on a strongly teleological shape. Appliers must make use of supplementation to cover gaps and remaining ambiguities, and of policing and integration to determine the most appropriate outcome. ${ }^{64}$ In doing so, they

58 Yambrusic, above, 248.

59 M S McDougall, H D Lasswell and J C Miller The Interpretation of International Agreements and World Public Order: Principles of Content and Procedure (New Haven Press, New Haven, 1994 Reissue with additions). xii-xvi.

60 McDougal, Lasswell and Miller, above, xvi.

61 McDougall, Lasswell and Miller, above, xvii-xviii.

62 F Jacobs "Varieties of Approach to Treaty Interpretation: with Special Reference to the Draft Convention on the Law of Treaties Before the Vienna Diplomatic Conference" (1969) 18 ICLQ 318, 324.

63 G Haraszti Some Fundamental Problems of the Law of Treaties (Akademiai Kiado, Budapest, 1973) 29.

64 McDougal, Lasswell and Miller, above, ix-xx. 
are explicitly making choices based on "basic community policy", and using the process of application to shape world order. ${ }^{65}$

This makes McDougal's approach subject to the same criticisms raised in respect of extreme teleological schemes, discussed below, in terms of legislating rather than clarifying law. This seems a curious blend, given the passionate commitment to uncovering actual expectations. It is difficult to accept that if genuine shared expectations are so important, they can be overridden, if not by a "clear" text, then by a wider programme.

\section{Teleological Interpretation}

A clear statement of the teleological approach is contained in the Harvard Research Draft Convention on the law of treaties, especially its proposed article 19 (a) and the associated commentary: 66

The process of interpretation ... cannot be ... a mere mechanical one of drawing inevitable meanings from the words in a text, or of ... discovering some pre-existing specific intention of the parties with respect to every situation ... In most instances ... interpretation involves giving a meaning to a text ... which is logical, reasonable and most likely to accord with and to effectuate the larger general purpose which the parties desired the treaty to serve.

This approach therefore focuses not on the literal meaning of the text per se, or the parties' intentions, but rather on the purpose of the treaty, and on giving effect to that. At a most basic level, this may be no more than using the treaty purpose as evidenced by the treaty text itself, to clarify the meaning of unclear provisions, as a natural corollary of the textual approach, or alternatively a matter of giving effect to the true intention of the parties, once established. ${ }^{67}$ However, the broader or more general the alleged purpose is allowed to be defined, the more scope there is for interpretive activism and "development" of the meaning, independent of the literal text or the actual will of the parties. Effectively, under a teleological approach, a treaty may have its terms amended or augmented, if this is found to be in keeping with the "general purpose". ${ }^{68}$ In fact it is highly arguable that draft article 19(a) also implies the doctrine of "emergent purpose", 69 so that even the

65 McDougal, Lasswell and Miller, above, ixxiii.

66 Harvard Research in International Law "Law of Treaties" (1935) 29 AJIL Supp 653, 939. [Harvard]

67 F Jacobs "Varieties of Approach to Treaty Interpretation: with Special Reference to the Draft Convention on the Law of Treaties Before the Vienna Diplomatic Conference" (1969) 18 ICLQ 318, 319.

68 G Haraszti Some Fundamental Problems of the Law of Treaties (Akademiai Kiado, Budapest, 1973) 113.

69 Jacobs, above, 320. 
original, intended purpose need not control, but rather a later conception of how the purpose should be understood in modern conditions. ${ }^{70}$

The approach is particularly directed at multilateral law-making treaties, and has been used to interpret and develop the constitutive documents of international organisations. ${ }^{71}$ It has arguably been adopted by the European Court of Human Rights, for instance in the Golder case, ${ }^{72}$ and may have resulted in the Court amending rather than interpreting the treaty.

\section{Critique}

In its more innocuous forms, the teleological approach is hardly a separate approach at all, but merely sensible use of available interpretative resources. Similarly, it could, if appropriately contained be no more than an outworking of the principle of effectiveness, which both major schools accept within limits. ${ }^{73}$ In determining how parties might give appropriate effect to a treaty, it seems only right that appropriateness be judged in the light of objects and purposes. The problem with the approach however is that given its broad conception, and its tendency to deny, at least in the Harvard Draft form, any hard and fast limitations or rules, ${ }^{74}$ it is equally or more likely to operate quite differently, as a licence to judicial activism or legislation. In the more developed form it may once again be seen not so much as a form of interpretation, but a quite separate activity, which may or may not be appropriate in certain cases, such as in dealing with the development of international

70 Harvard Research Draft Convention on the law of treaties, Article 19(a) includes in part:

... the circumstances of the parties at the time the treaty was entered into, the change in these circumstances sought to be effected ... and the conditions prevailing at the time the interpretation is being made, are to be considered in connection with the general purpose which the treaty is intended to serve.

Harvard Research in International Law "Law of Treaties" (1935) 29 AJIL Supp 653, 937.

71 See C F Amerasinghe Principles of the Institutional Law of International Organizations (Cambridge University Press, England, 1996), 25. Jacobs, above, cites as generally accepted that for constitutional documents of international organisations objects and purposes may have to be interpreted in the light of subsequent developments in international organisation.

72 Golder Case (1975) 57 ILR 209 (ECHR); see Sir I Sinclair The Vienna Convention on the Law of Treaties (2 ed, Manchester University Press, Manchester, 1984) 131-133.

73 G G Fitzmaurice "The Law and Procedure of the International Court of Justice, 1951-4: Treaty Interpretation and other Treaty Points" (1957) 33 BYIL 203, principle IV; H Lauterpacht "Restrictive Interpretations and the Principle of Effectiveness in the Interpretation of Treaties" (1949) 26 BYIL 48, 74.

74 Harvard, above, 939. 
organisations. ${ }^{75}$ Given its capacity to undermine international law as the product of consenting states, its implementation as a general approach to interpretation appears both unwarranted and unlikely.

\section{DEVELOPMENT OF THE CONVENTION ARTICLES}

\section{A Early Activity}

The nature or possibility of legal rules covering interpretation remained contentious throughout the 1950s and early 60s. Many of the key contributions to the academic debate come from this period. ${ }^{76}$ Despite statements by the majority of the ICJ adopting a textual approach, ${ }^{77}$ the debate continued off and on through the work of the International Law Institute (ILI) from 1950 through to 1956, and it seemed to contemporaries that the attempt at resolution was abandoned due to impossibility. ${ }^{78}$ With Fitzmaurice as Special Rapporteur the ILI did agree articles in 1956 adopting a textual approach, but in vague and uncertain terms. ${ }^{79}$ It is therefore hardly surprising that members of the ILC initially approached their consideration of interpretation with pessimism and scepticism. ${ }^{80}$

75 The ILC in its commentary explicitly decided not to include any commentary on interpretation of international organisation instruments, as the matter was controversial, and a special case: ILC Commentary (1964) II YBILC, 205, para 17. [ILC Commentary 1964]

76 See for instance G G Fitzmaurice "The Law and Procedure of the International Court of Justice, 1951-4: Treaty Interpretation and other Treaty Points" (1957) 33 BYIL 203; G G Fitzmaurice "The Law and Procedure of the International Court of Justice: Treaty Interpretation and Certain other Treaty Points" (1951) BYIL 1; H Lauterpacht "Restrictive Interpretations and the Principle of Effectiveness in the Interpretation of Treaties" (1949) 26 BYIL 48; J Stone, "Fictional Elements in Treaty Interpretation" 1 Sydney Law Review (1955) 344, and the contributions of M Huber (1952) 44 Annuaire de l'Institut de droit international 199; L Eckert (1950) 43 Annuaire de l'Institut de droit international 366; H Lauterpacht (1950) 43 Annuaire de l'Institut de droit international 433, G G Fitzmaurice (1956) 56 Annuaire de l'Institut de droit international 317, and others to ILI debates.

77 Admissions Case [1950] ICJ 8. Competence Case [1948] ICJ 63.

78 Stone, above, 345 and also consider footnote 7 a of his paper.

79 G G Fitzmaurice (1956) 56 Annuaire de l'Institut de droit international 317; F Jacobs "Varieties of Approach to Treaty Interpretation: with Special Reference to the Draft Convention on the Law of Treaties Before the Vienna Diplomatic Conference" (1969) 18 ICLQ 318, 322.

80 ILC Proceedings (1964) YBILC I 275-278, comments of Messrs Tunkin, Briggs, de Luna, Tabibi, Amado, Ruda and Rosenne. [ILC Proceedings 1964] 


\section{B Work of the ILC}

\section{4}

Before considering the content of legal rules on interpretation, the ILC had to decide whether such rules were possible or desirable. ${ }^{81}$ The scepticism of the Harvard Draft, together with the strength of the debate between the schools made the question a real issue, and it clearly was an option to leave interpretation out of the eventual codification of the law of treaties. Nevertheless, both the Special Rapporteur and the Commission came quite quickly to the conclusion that the various maxims often applied to interpretation, were not legal rules, but only potential aids and guides depending on a particular situation or text. ${ }^{82}$ They should therefore be excluded from any draft, even as mere examples of useful tools. ${ }^{83}$ However it should be possible and therefore desirable to identify the "comparatively few rules" constituting the "strictly legal basis" of interpretation", 84 which is what the ILC set out to do.

This approach seems uncontroversial today. It recognises that interpretation is always a matter of addressing a particular case, albeit within some framework, but not of applying rigid grammatical rules to produce a mechanical answer. This at least recognises the limits of textualism. However, in taking this approach Sir Humphrey Waldock, and the Commission by adopting his words in slightly watered down form, ${ }^{85}$ based their argument on the need to reinforce or establish the importance of text. Apart from the obvious point that some basic rules will help to avoid arbitrary interpretation, the other main reason given is the need to "take a clear position in regard to the role of the text", given "the tendency of doctrinal differences" to "weaken the significance of the text". 86 Even in deciding whether to have legal rules, battle lines were being drawn on the main doctrinal dispute between text and intentions.

The question therefore becomes, did the ILC follow through from this reasoning, to propose an essentially textual answer to the question of the basis or purpose of treaty interpretation? There seems little doubt the members were led to begin from this point by

81 Sir H Waldock Third Report of the Special Rapporteur on the Law of Treaties to the ILC (1964) YBILC II 5, 53 para 1, 54 - 55, para 8 [Waldock Third Report]; ILC Proceedings 1964, above.

82 Waldock Third Report, above, 54, para 6; ILC Commentary 1964, above, 200, para 5.

Waldock Third Report, above, 54, para 8.

4 Waldock Third Report, above; ILC Commentary 1964, above, 200, para 6.

Waldock Third Report, above; ILC Commentary 1964, above.

86 Waldock Third Report, above. The ILC Commentary 1964, above, merely argues the desirability of taking a clear position on the text. 
their Special Rapporteur. Waldock's Third Report, while admitting the controversy, accepts the textual as the "majority" position, and explicitly promotes it as the resolution to the debate. ${ }^{87} \mathrm{He}$ acknowledges the 1956 ILI articles and Fitzmaurice's six principles as "inspiration" in proposing the original drafts, ${ }^{88}$ which follow a clearly textual approach. Proposed article 70 (later proposed article 69) explicitly seeks to incorporate Fitzmaurice's first three and sixth principles (textuality, ordinary meaning, integration and contemporaneity ) - "the very essence of the textual approach" as well as the pacta sunt servanda principle of interpretation in good faith. ${ }^{89}$ For Waldock, the elucidation of the meaning of the text is both the "starting point" and "purpose" of interpretation. ${ }^{90}$

Waldock's views clearly enjoyed support amongst members, ${ }^{91}$ as evidenced not least by their willingness to adopt much of the text of Waldock's report as their commentary with apparently minor amendments. ${ }^{92}$ One member explicitly referred to Vattel's basic rule, ${ }^{93}$ and the Chairman considered it was in fact implicit in the draft, although he would prefer not to lay "too much stress" on it. ${ }^{94}$ However it is clear from a reading of the Commission's first discussions on the draft articles that all of the major schools had some influence on at least some Commissioners' views. Messrs Tabibi and Pessou were most explicit in stressing the primacy of the intentions of the parties, ${ }^{95}$ and Messrs Rosenne and Yasseen also stressed the importance of intentions, and the need to go beyond merely textual analysis. ${ }^{96} \mathrm{Mr}$ Bartos on the other hand adopted the most obviously teleological approach, preferring to rely on the "spirit" and the objects and purposes of the treaty, considering they should be the basis of interpretation, not the text. ${ }^{97} \mathrm{Mr}$ Briggs on the

87 Waldock Third Report, above, 52- 61.

88 Waldock Third Report, above, 55, para 10.

89 Waldock Third Report, above, 56, para 14.

90 Waldock Third Report, above, 56, para 13.

91 See for example ILC Proceedings (1964) YBILC I 280, para 79, Chairman Ago, 277, para 36, Mr Ruda, 280, para 75-76, Mr Pal; and to a lesser extent Mr Rosenne, 278, para 40, Mr Briggs, 275, para 10 .

92 Compare Waldock Third Report, above, 53ff, paras 1-8, and ILC Commentary (1964) II YBILC 199 paras 1-6.

93 ILC Proceedings 1964, above, 277, para 33, Mr Ruda.

94 ILC Proceedings 1964, above, 280, para 79.

95 ILC Proceedings 1964, above, 276, para 25, Mr Tabibi; 278, para 46.

96 ILC Proceedings 1964, above, 278, para 40, Mr Rosenne; 286, para 49, Mr Yasseen.

97 ILC Proceedings 1964, above, 279-280, paras 64, 67; 281, para 91. 
other hand appeared to adopt a cautiously "inclusive" approach, based loosely on the Harvard draft.

Thus while Waldock continued to assume the Commission's "strong predilection for textual interpretation" at least in 1964, ${ }^{98}$ it can be seen that consideration and redrafting of the proposed articles involved a process of compromise and movement away from thoroughgoing textuality. Reference to "natural" meaning was quickly dropped, and the "object and purpose" of the treaty was brought into paragraph 1, instead of the Third Report's proposed ancillary position. ${ }^{99}$ In addition, small but significant changes appeared in the commentary: references agreeing with "the primacy of the text" were toned down or disappeared, ${ }^{100}$ and while the text is still the starting point, it is no longer the starting point and purpose of interpretation. ${ }^{101}$ Similarly, in the discussion of the degree to which recourse could be had to supplementary means, a traditional battleground of the textual/intentions debate, there is evidence of some compromise, to lessen the effects of too strict a textual approach, by allowing recourse at any time to "confirm" a meaning. ${ }^{102}$ Also, evidence of concordant subsequent practice is moved up to the first article, as a primary or authentic means of interpretation. ${ }^{103}$ Textuality retains explicit pride of place in the commentary, but it is clear that even in 1964 the Commission did not agree or intend a purely textual approach.

The formula of elucidation of the meaning of the text as the "starting point for interpretation" is in fact remarkably close to Lauterpacht's proposed 1950 article. ${ }^{104}$ Here it is shorn of reference to the search for intentions as the "principal goal" for interpretation, and there is recognition that there is to be no ab initio investigation of parties' intentions. ${ }^{105}$ However, given that the ILC is describing a starting point, not an endpoint, or indeed "the

98 ILC Proceedings 1964, above, 314, para 71.

99 See ILC Proceedings 1964, above, 275 para 11, Mr Brigg's objection; compare Sir H Waldock Third Report of the Special Rapporteur on the Law of Treaties to the ILC (1964) YBILC II 5, draft Article 70, para 1 with ILC Proceedings 1964, above, 199, draft Article 69, para 1.

100 Compare ILC Commentary (1964) II YBILC, above, 200, para 3 (c) and 200, para 9 with Waldock Third Report, above, 54, para 5, and 56, para 13.

101 ILC Commentary 1964, above, 201, para 9.

102 ILC Commentary 1964, above, 204-205, paras 15-16.

103 ILC Commentary 1964, above, 199, draft Article 69, para 3. See also Waldock's comment on the decision of the Commission, Sixth Report of the Special Rapporteur (1966) II YBILC 98, para 18. [Waldock Sixth Report]

104 See H Lauterpacht (1950) 43 Annuaire de l'Institut de droit international 433.

105 ILC Commentary 1964, above, 201, para 9. 
purpose" of interpretation, it is highly likely that even Lauterpacht could agree with the expression chosen. By leaving out reference to overriding purpose, it appears the ILC was adopting exactly the approach to contentious issues which Lauterpacht had noted: the adoption of vague or ambiguous language, or the deletion of a difficult phrase, to cover a lack of actual agreement, common understanding or intention. ${ }^{106}$ Perhaps the most important conclusion which can be drawn from the 1964 deliberations of the ILC was that the members had no common intention on the fundamental purpose of treaty interpretation, and that therefore all their tentative conclusions on methods and sources were attempts to reach compromises that adherents of different approaches could agree with.

\section{6}

In 1966, the ILC considered the responses of governments, and a further report from the Special Rapporteur. ${ }^{107}$ While the report detects "general endorsement" for the ILCproposed starting point from governments, it did note that there were government proponents, for either a more explicitly textual or an avowedly intentions purpose as the basis for interpretation. ${ }^{108}$ This suggests at least some states recognised that the ILC was fudging the basic issue, hoping for some workable compromise.

Both the Sixth Report and the eventual commentary to the revised draft articles still appear strongly textual: The commentary to draft article $27^{109}$ largely repeats the 1964 logic making text the starting point, including Huber's comment quoted above. ${ }^{110}$ United States proposals to de-emphasise ordinary meaning, as just one of six factors were rejected, ${ }^{111}$ as were proposals from some states and several Commission members to raise preparatory works and other supplementary means to the status of primary means. ${ }^{112}$ It is therefore

$106 \mathrm{H}$ Lauterpacht "Restrictive Interpretations and the Principle of Effectiveness in the Interpretation of Treaties" (1949) 26 BYIL 48, 77-78.

107 Still Sir H Waldock Sixth Report of the Special Rapporteur (1966) II YBILC.

108 Waldock Sixth Report, above, 94, para 2; see 91-93, contrasting positions of Czechoslovakia and Hungary, amongst others.

109 Formerly Article 69/70, to eventually become Article 31

110 Commentary on the draft articles, ILC Proceedings (1964) YBILC I 220, para 11. See M Huber (1952) 44 Annuaire de l'Institut de droit international 199.

111 Waldock Sixth Report, above, 94-95, para 3.

112 Waldock Sixth Report, above, 99, para 19-20; Report of the International Law Commission on Draft Articles (1966) II YBILC 220, para 10. [ILC Commentary 1966] 
not surprising that states tended to view the drafts as incorporating "the textual approach". 113

In reality the ILC further qualified the textual approach, to the point where it should be recognised as something different. The Proceedings show that the members remained deeply divided. The eventual compromise on article 28/32, on supplementary means, appears to be the most that a textually-inclined majority would accept, and the least that a strong minority could live with. ${ }^{114}$ A significant proportion of debating time was taken up with supplementary means, with the minority strongly advocating that the distinction between primary and secondary means be abolished, and/or that at least preparatory works be included in article 27/31. ${ }^{115}$ The debate can be seen as analogue for one not explicitly held, over the basic purpose of interpretation.

In the end, the minority appears to have given up a fight it could not win, but to have found more common ground with the Special Rapporteur in another area which helped to mitigate the loss. This was on the critical issue of whether there was any hierarchy of means, or whether the process of interpretation was to be regarded as a "unity". In response to United States and other state criticisms that the original drafts set up an inappropriate hierarchical system, with ordinary meaning pre-eminent, Waldock suggested that the ILC had never intended to set up a hierarchy: there was to be a general rule, not rules in priority order. All the various elements would be thrown into the "crucible", in a "combined operation". 116

This crucible analogy was taken up with alacrity by the dissenters, ${ }^{117}$ and was confirmed in the commentary, where the unity of the process of interpretation was also stressed. ${ }^{118}$ This placing of all interpretative means in article $27 / 31$ on a par significantly undermines any textual predominance in the general rule. While the textualists can and $\operatorname{did}^{119}$ read references to context, object and purpose as to be found primarily from the text, such a reading is not self-evident from the text, and in any case the article now clearly

113 Waldock Sixth Report, above, 91-93. See for instance the views of Israel, and the United Kingdom.

114 ILC Proceedings (1966) I Pt II, 271, para 41, Sir H Waldock. [ILC Proceedings 1966]

115 ILC Proceedings 1966, above, 187, para 35, Mr Briggs; 197, para 41, Mr Tsuoroka. See 199-207 for the divided views on preparatory works.

116 Waldock Sixth Report above, 95, para 4.

117 ILC Proceedings 1966, above, 186, para 19, Mr Rosenne.

118 Report of the International Law Commission on Draft Articles (1996) II YBILC 169, 220-221. [ILC Commentary 1966]

119 ILC Proceedings 1966, above, 188, paras 38-39, Mr Reuter. 
contained, on an equal footing in the "crucible" approach, explicit reference to special meaning intended by the parties, and concordant subsequent practice. ${ }^{120}$ Also, even the confirmed relegation of preparatory works and other "supplementary" means is modified, not only by the possibility of their "confirmatory" use, but also in the commentary, where the means in article 28/32 are brought within the "unity of the process of interpretation". ${ }^{121}$

Given the now extensive resort to extrinsic means of interpretation - that is, from outside the actual text of the treaty - and the fact that the object and purpose of a treaty can be seen to be analogous to the intentions of its drafters, not a mere extrapolation from the text, it is clear that while interpretation is still to start from the text, as the most obvious place to look first, a wide range of sources and approaches can and should be used. While the ILC remains studiously silent on the purpose of treaty interpretation, it must be said that the evolving approach of the draft articles is more consistent with as broad an enquiry as necessary to establish the will of the parties, rather than a simply linguistic exercise to clarify the meaning of a text. No doubt the continued silence on this critical point of difference allowed the members to reach a text that all could accept, but both that text and the work behind it show permission, even encouragement, to depart from a textual approach.

\section{Relevance of the ILC's work}

The debate over the relative merits of different methods and sources for interpretation raises an issue about the relevance of the work of the ILC to our understanding of the law. What recourse should be had to the ILC work when interpreting articles 31 and 32? Clearly the Vienna Conference agreed the articles, not the ILC, albeit without significant amendment from the ILC drafts. ${ }^{122}$ Should we have reference to preparatory works to interpret articles 31 and 32? In any case, do the deliberations of the ILC amount to preparatory works? The ILC itself was alive to the last issue, and discussed it in $1966 .{ }^{123}$

In the first place, it must be held that whatever position one takes on the appropriate approach to interpretation, the articles are ambiguous on their face and necessitate a wide

120 Article 27/31, paras 3 (b) and 4 .

121 ILC Commentary 1966, above, 220, para 10.

122 Article 31(3)(a) was broadened by the addition of "or the application of its provisions", and (3)(b) regarding subsequent practice was amended so that such practice had to demonstrate the "agreement" of the parties, not their "understanding; See M Villiger Customary International Law and Treaties (Martinus Nijhoff, Dordrecht, 1985) 331.

123 ILC Proceedings (1966) I Pt II, 201, para 35, Mr Rosenne, raising the issue; 205, para 25, Chairman Yasseen, replying; 205, para 27, Mr Tunkin, qualified agreement with Chairman that proceedings were preparatory works; 206, para 34, Mr El-Erian, also supporting ILC proceedings as preparatory work. 
recourse to other sources. The meaning of "object and purpose" is ambiguous, as is the specific content of the good faith obligation. It is not clear how in article 31(4) a special meaning is to be established: as this is a "primary" means of interpretation, does this imply one can always have recourse to the dealings of the parties to check for special meanings? Similarly the consequences of confirmatory resort to supplementary means are not clear: if they do not confirm but contradict an otherwise apparently "clear" meaning, do they have weight?

In the light of such ambiguities, it is both necessary and desirable to refer to the ILC work. The ILC accepted that their work could give insight into the intended meaning, especially where adopted unchanged. ${ }^{124}$ While it was possible for a conference to attribute a different meaning to the same text, ${ }^{125}$ the meaning intended by the ILC is relevant to interpretation. Importantly, the ILC also recognised that it would be counter-productive to try to define preparatory works, as this might only lead to exclusion of relevant evidence. ${ }^{126}$ This confirms not only that the ILC work is an important source in understanding the content of the law, but also that the interpretation enquiry is a broad one. The ILC's conceptualisation of a "crucible" is self-reinforcing. Whatever position one takes on the apparent clarity or ambiguity of the text of the articles, the developed understanding of the ILC of the need to approach interpretation as an integrated, unified process should shape how the modern interpreter of any treaty approaches their task.

\section{The Vienna Conference}

The Conference adopted the draft articles largely unchanged, by unanimous votes. ${ }^{127}$ While this strengthens the importance of the ILC's work, it does not suggest a common understanding on what the articles meant. Debate continued about the merits of different approaches, $^{128}$ and states were divided on whether article 27 embedded textualism, or provided for parity of means. ${ }^{129}$ There was a similar split on article 28 , on whether it allowed liberal or restricted access to supplementary means. ${ }^{130}$ The proportions are

124 See ILC Proceedings 1966, above, 205, para 25, Chairman Yasseen.

125 See ILC Proceedings 1966, above, 205, para 27, Mr Tunkin.

126 Report of the International Law Commission on Draft Articles (1996) II YBILC 169, 223 para 20.

127 See M Villiger Customary International Law and Treaties (Martinus Nijhoff, Dordrecht, 1985): Article 27 was adopted 97 - 0, Article 28, $101-0$.

128 Villiger, above, 332.

129 Villiger, above, 333. Seven states agreed with the Commission on parity of means in Article 27, while 19 thought the Article required the textual approach.

130 Villiger, above; the split was eight for liberal, 15 for restricted access. 
remarkably similar to those of the opposing views in the ILC, where perhaps five out of 18 members adopted a consistently more "liberal" line. ${ }^{131}$

It is suggested that states were as far from common intention on the basis or purpose of interpretation as the ILC. Amendments from intentions or a textual perspectives were decisively voted down, ${ }^{132}$ suggesting no real agreement about what underpinned the articles. The result has the appearance of delegates sticking to a workable compromise, fudging the difficult issue as did the ILC. While it is probably true that most states thought they were adopting a textual approach, perhaps with reasonable scope to adopt other means, they specifically avoided saying so in the text. The ILC draft can, in that sense, be seen as a work of some genius, as it allowed the parties, to reach agreement on a text, without first having to resolve the old doctrinal disputes.

This leaves the implication that the relative claims of the schools remain inherent but unresolved in the wording, giving later interpreters opportunity to draw on the insights of the schools if they wish. The extent to which this has occurred, and whether it has resolved anything about the nature of the law or its underpinnings, is examined in sections IV and $\mathrm{V}$.

\section{ATTITUDES TO TREATY INTERPRETATION FROM 1969}

Whatever the intentions of the drafters, or the delegates at the conference, articles 31 and 32 have usually been taken to require either the textual, or a closely related contextual approach. State practice, academic writings, and to a lesser extent arbitral and judicial decisions tend to confirm this as the majority, but not the only, view. Given this background, the attitude of the majority in the ICJ in the 1990's examined in section V below, is not surprising, but is rather a further step in an emerging predominance of textualism. Whether this is predominance should be confirmed must be returned to later.

\section{A State Practice}

In the period following the Vienna Conference it is possible to detect conflicting views on the basis for interpretation. The articles were already being referred to as reflecting custom, ${ }^{133}$ or being treated as declaratory of principles of international law. ${ }^{134}$ On the law's content, some governments stressed the importance of intentions. ${ }^{135}$ However, more

131 ILC Proceedings (1966) I Pt II. See especially 199-207, the debate on supplementary means.

132 Villiger, above, 332.

133 Villiger, above, 334, position of Austrian Government.

134 Villiger, above, 335, position of Federal Republic of Germany; 335, position of Sweden.

135 Villiger, above, 334 - 335, for instance, Germany and Belgium. 
prevalent was the view that the articles embodied textuality. ${ }^{136}$ The United Kingdom courts have sometimes consciously adopted a teleological, or what they call the "European" approach, and have been arguably slow to recognise the convention rules. ${ }^{137}$ Nevertheless, it is easy to agree with Villiger that many states, by the 1980s, regarded the articles as declaratory, and considered they embodied the textual approach. ${ }^{138}$ The approach of the ILC appears eroded, in that article 31(1) alone appears often to be taken to be the "general rule", not the totality of article 31, and access to supplementary means is taken to be restrictive. ${ }^{139}$ No doubt state practice is not sufficiently uniform or widespread to amount to subsequent practice under article 31(3)(b), but paradoxically, it may amount to supplementary evidence admissible under article 32. Of course, states adopting a textual reading of the articles may consider such evidence as unnecessary and inadmissible, if they consider the articles meaning is "clear".

\section{B Courts and Arbitral Tribunals}

Courts and tribunals have been more ambivalent about the basis for treaty interpretation, at least until the ICJ in the 1990s. There was willingness to apply article 31's general rule even before its ratification, as representing "generally accepted principles of international law", 140 or "traditional canons". ${ }^{141}$ However, different tribunals and judges have taken quite different approaches to what the articles require, indicating no early consensus on their meaning. The European Court of Human Rights in Golder appeared to be adopting exactly the expressed reasoning of the ILC, that the general rule defines "the process of interpretation as a unity, a single combined operation", with all the elements of the article on an equal footing. ${ }^{142}$ While this suggests that the Court was adopting the implicit compromise between text and other means of interpretation proposed by the ILC,

136 Villiger, above, 336, position of the United Kingdom Government in the Golder Case (1975) 57 ILR 209 (ECHR). As well as the United Kingdom, Villiger identifies Austria, Canada, France, Italy, the Netherlands, South Africa, Switzerland, and even the United States as exhibiting at least some agreement that the textual approach predominates.

137 Fothergill v Monarch Airlines (1980) 2 All ER 696 (CA); James Buchanan case (1977) 1 All ER 518 (CA); See Villiger, above, 337; see also R Gardiner "Treaty Interpretation in the English Courts since Fothergill v Monarch Airlines" (1995) 44 ICLQ 620.

138 Villiger, above, 337, para 499.

139 Villiger, above, 337, para 499.

140 Golder Case (1975) 57 ILR 209 (ECHR), 213-214, para 29. See discussion in Sir I Sinclair The Vienna Convention on the Law of Treaties (2 ed, Manchester University Press, Manchester, 1984) 131-133.

141 Beagle Channel Arbitration (1979) 52 ILR 124, para 7(d)(i); Villiger, above, 339, para 503.

142 Golder, above, 214, para 30. 
Fitzmaurice and Verdross at the time, ${ }^{143}$ and Sinclair later ${ }^{144}$ were highly critical of the departure from an available ordinary meaning in favour of something incompatible with it. While the disagreement appears to be a principled one based on the different perspectives of textualists and those prepared to adopt a more teleological approach, there is no doubt some plausibility in Sinclair's description of the Court's adherence to the articles as "lip service", 145 and Fitzmaurice's accusation that the Court was in fact using the articles to confirm an interpretation reached by other means. ${ }^{146}$ That the dispute was possible emphasises the breadth of the articles, the lack of true consensus in their development, and the scope for ongoing divergence on their interpretation.

Some early arbitral decisions do however suggest a more consistently textual approach. The Beagle Channel Arbitration, involving the interpretation of an 1881 boundary treaty between Argentina and Chile, was resolved on a textual analysis of "the more natural [meaning] on the basis of the actual language of the text". 147 The Arbitral Tribunal in the Young Loan Arbitration actually applied the articles, moving from unclear text to context and objects and purposes, and on to preparatory works to resolve the question of what amounted to a "depreciation". ${ }^{148}$ However, as Villiger has pointed out, the panel may only have moved on to other means, because the text could not resolve the issue. ${ }^{149}$ The case does not stand for any clear acceptance of parity of means, even within article 31.

The attitude of the ICJ to the articles during the 1970s and into the 80s seems at most ambivalent. McDougall has criticised the Court for being overwhelmingly textual in its approach, ${ }^{150}$ while noting some exceptions from individual judges, such as Judges de Castro and Dillard in the Namibia Advisory Opinion. ${ }^{151}$ While McDougall's view is

143 Golder, above, 245, dissenting opinion of Sir G Fitzmaurice; 224, dissenting opinion of Verdross.

144 See Sir I Sinclair The Vienna Convention on the Law of Treaties (2 ed, Manchester University Press, Manchester, 1984) 131-133.

145 Sinclair, above, 131.

146 Golder, above, 247, Fitzmaurice.

147 Beagle Channel Arbitration (1979) 52 ILR 124, 145, para 48.

148 Young Loan Arbitration (1971) 59 ILR 495, 530-543.

149 M Villiger Customary International Law and Treaties (Martinus Nijhoff, Dordrecht, 1985) 341.

150 M S McDougall, H D Lasswell and J C Miller The Interpretation of International Agreements and World Public Order: Principles of Content and Procedure (New Haven Press, New Haven, 1994 Reissue with additions) xlii-xlv.

151 McDougall, Lasswell, and Miller, above, xliii, xlv; Legal Consequences for States of the Continued Presence of South Africa in Namibia (South West Africa) Notwithstanding Security Council Resolution 276 (1970) (1971) ICJ 16, 182, separate opinion of Judge de Castro; 157, separate opinion of Judge Dillard. [Namibia] 
undoubtedly coloured by his view of the articles themselves, there is evidence of textual analysis in the Fisheries Jurisdiction Case, ${ }^{152}$ and in some of the separate opinions in the WHO Advisory Opinion. ${ }^{153}$ However, in a much quoted paragraph from the Namibia Advisory Opinion, the Court is "[m]indful ... of the primary necessity of interpreting an instrument in accordance with the intentions of the parties at the time of its conclusion". ${ }^{154}$ While the phrase is used in connection with settling a question of intertemporal law as it affects interpretation, ${ }^{155}$ it does suggest the Court still gave credence to the view that the primary object of interpretation is to establish intentions. The wording contains no hint of Huber's stipulation, that that intention is to found in the expressed text.

It can be inferred the Court was inclined to avoid difficult questions of interpretation, especially where they tended to divide the Court. Thus, in the WHO Advisory Opinion, the Court redefined the question to be answered, thereby avoiding having to resolve the key issue of whether "revision" could include "termination". 156 The Court was divided on the merits of purely textual interpretation, with at least three judges seeing the need to avoid "formalism", and to resolve the issue by reference to preparatory works. ${ }^{157}$ Thus, while a textual approach often appeared in the jurisprudence of the Court, it remained contested, and it was not until the 1990s that the Court felt able or obliged to state an approach based on primacy of text, formally linked to articles 31 and 32.

\section{Academic Writers}

Modern academic writing usually either argues or assumes that the articles encapsulate a textual or contextual basis and approach. This is frequently true of writers who clearly disagree with such an approach, for instance, McDougall, 158 Haraszti. ${ }^{159}$ and

152 Fisheries Jurisdiction Case (UK/Iceland) (1973) ICJ 9 para 17.

153 WHO Advisory Opinion (1980) ICJ 73, 128, separate opinion of Judge Mosler; 185, separate opinion of Judge Sette-Camara; McDougall, Lasswell, and Miller, above, xlii-xliii.

154 Namibia, above, 31, para 53.

155 Namibia, above.

156 WHO Advisory Opinion, above, 73, para 42; Sir I Sinclair The Vienna Convention on the Law of Treaties (2 ed, Manchester University Press, Manchester, 1984) 123.

157 Sinclair, above, 124. Judges Gros, Ago and El-Erian saw the limits to the textual or semantic arguments, and resorted to preparatory works; contrast Judges Mosler and Sette-Camara, WHO Advisory Opinion, above, 73.

158 Text of M S McDougall's argument to the conference (1968) 62 AJIL 1021; M S McDougall, H D Lasswell and J C Miller The Interpretation of International Agreements and World Public Order: Principles of Content and Procedure (New Haven Press, New Haven, 1994 Reissue with additions) xl.

159 See G Haraszti Some Fundamental Problems of the Law of Treaties (Akademiai Kiado, Budapest, 1973) 102-103. 
Yambrusic. ${ }^{160}$ Jacobs is far more sympathetic towards textualism. ${ }^{161} \mathrm{He}$ saw the articles as hierarchical, with ordinary meaning and therefore text coming first. ${ }^{162}$

Sinclair also appears to favour ordinary meaning. ${ }^{163}$ His position, and his view on the content of the articles seems closest to the kind of contextual synthesis proposed by McNair, to which Sinclair refers. ${ }^{164}$ Text in context, and in the light of object and purpose gathered from the text, are the basis of interpretation. ${ }^{165}$ The interpreter can and will have access at various times to all the potential sources and methods available within the articles, but must have regard to their respective weights, or place in a hierarchy. ${ }^{166}$ If this seems well removed from the advertent intention of the ILC, it nevertheless can be said to represent an "orthodox" position, more recently reflected in the ICJ.

Standing out against such an orthodoxy is the position of Villiger. He makes use both of the text of the articles, and the proceedings of the ILC to argue for a more permissive approach. Ordinary meaning is both relative, and multiple, as article 31 itself implies. ${ }^{167}$ All of the elements within article 31 are of potentially equal value for interpretation, and this was the explicit intention of the ILC as expounded in the "crucible" analogy. ${ }^{168}$ The parties to a dispute are intended to have liberal recourse to supplementary means, because they can be used at any time to confirm, or where there is ambiguity, which will be frequent or prevalent. ${ }^{169}$ The articles therefore provided a highly flexible range of possibilities, which nevertheless governments and courts have tended not to use, sticking to inappropriately narrow textualism. ${ }^{170}$

160 E S Yambrusic Treaty Interpretation Theory and Reality (UPA, Lanham MD, 1987) 186.

161 F Jacobs "Varieties of Approach to Treaty Interpretation: with Special Reference to the Draft Convention on the Law of Treaties Before the Vienna Diplomatic Conference" (1969) 18 ICLQ 318, 342-343.

162 Jacobs, above, 326. See discussion above section III, for ILC's view on hierarchy.

163 See for instance his criticism of the majority in Golder Case (1975) 57 ILR 209 (ECHR).

164 Sir I Sinclair The Vienna Convention on the Law of Treaties (2 ed, Manchester University Press, Manchester, 1984) 115 and Sinclair's footnote 8.

165 Sinclair, above, 118.

166 Sinclair, above, 154

167 M Villiger Customary International Law and Treaties (Martinus Nijhoff, Dordrecht, 1985) 343, para 512

168 Villiger, above, 344, para 513; 345, para 516.

169 Villiger, above, 346, para 518.

170 Villiger, above, 345, para 516. 
Villiger does not choose between the schools, or argue that the articles adopt one school. ${ }^{171}$ While he clearly considers elements of all three main schools are present in the articles, he does not identify a clear basis for interpretation, or have anything to say on the purpose. This is unfortunate if unsurprising, given that his primary purpose when considering the articles is to examine an example of divergence between treaty law and emerging custom. ${ }^{172}$ It will be argued in the remaining two sections that disagreement on purpose is what continues to impede progress in our understanding of interpretation, and this critical issue needs to be addressed if any resolution is to be attempted.

\section{THE INTERNATIONAL COURT AND INTERPRETATION IN THE $90 S$}

By the early 1990s therefore, there was increasingly widespread agreement that articles 31 and 32 represented both the conventional and customary law on treaty interpretation. This usually but not universally accompanied a view that the articles demanded primarily a textual approach, with other means of interpretation available but subordinate to the text of a treaty and the ordinary meaning. As will be seen from analysis of the cases, the ICJ finally adopted this orthodox approach, but not without critical dissents which drive us back to consider the basis of treaty interpretation.

\section{A Libya v Chad}

\section{Background}

The Case Concerning the Territorial Dispute (Libyan Arab Jamahiriya/Chad) (Libya $v$ Chad) came before the ICJ in 1990, based on a Framework Agreement ("Accord-Cadre") between the parties of 1989.173 It concerned in the opinion of Chad a boundary dispute over an existing but disputed border between the countries, and in the opinion of Libya, a question of the extent of Libya's territorial rights to the south, as Libya contended there was no existing conventional boundary in the affected area. ${ }^{174}$ Chad relied mainly on a boundary argued to have been determined by the Treaty of Friendship and Good Neighbourliness, between the United Kingdom of Libya and France in 1955 (the 1955 Treaty), ${ }^{175}$ although it did also argue in the alternative that the border could also be determined by reference to

171 Although reference to "object and purpose" does permit teleology, and preparatory works, among others, are there to shed light on intentions: Villiger, above, 343, para 513; 345, para 517.

172 Villiger, above, 342, paras 508-510. His analysis is one case study in his larger work on the relationship between treaty and customary law.

173 Libya v Chad [1994] ICJ 6, 8-9, para 1.

174 Libya $v$ Chad, above, 12-14, para 17.

175 France was the then colonial power responsible for the area that became the State of Chad, on independence in 1960 
earlier treaties, if the Court did not accept its interpretation of the 1955 Treaty. ${ }^{176}$ Libya on the other hand interpreted the treaty as not agreeing or determining the frontier in the affected area, but only confirming other frontiers which had already been agreed, such as that between Libya and Tunisia, to Libya's west. ${ }^{177}$

\section{The issue}

The dispute therefore turned on interpretation of the 1955 Treaty, and in particular its article 3 and the relevant annexe 1 . The authoritative French text reads: ${ }^{178}$

Les deux Haute Parties contractantes reconnaissent que les frontières séparant les territoires de la Tunisie, de l'Algérie, de l'Afrique occidentale française et de l'Afrique équatoriale française d'une part, du territoire de la Libye d'autre part, sont celles qui résultent des actes internationaux en vigueur à la date de la constitution du Royaume Uni de Libye, tels qu'ils sont définis dans l'échange de lettres ci-jointes (annexe I).

The Court did in fact determine the matter on the basis of its interpretation of the treaty, in favour of the Chad interpretation, that the 1955 Treaty did indeed set all the frontiers, including between Libya and what is now Chad. ${ }^{179}$ This is not surprising: the text of the treaty is relatively straightforward, and is supported by the context of other articles in the treaty, which also suggest that it was an object of the treaty to set the frontier. ${ }^{180}$ The conclusion is also supported by reference to preparatory works, and by reference to the subsequent attitudes of the parties to their mutual frontier. ${ }^{181}$

\section{The court's approach to interpretation}

More interesting is the approach which the Court took to interpretation. It finally and explicitly confirmed article 31 as mandatory, because it reflected customary international

176 Libya $v$ Chad, above, 15, para 21.

177 Libya $v$ Chad, above, 22, para 43.

178 Libya $v$ Chad, above, 20-21, para 39. Translation by the ICJ Registry is included in the English text of the case. The annexe lists several agreements between the various colonial powers at the beginning of the $20^{\text {th }}$ century defining spheres of influence and frontiers. The critical ones for this dispute are the Franco-British Convention of 1898 (and an 1899 Declaration completing it), and the decisive Franco-British Convention of 1919.

179 Libya $v$ Chad, above, 22-28, paras 42-56; 40, para 77, Finding (1).

180 Libya $v$ Chad, above, see paras $45-51$ on the text of the treaty; para 52 re object and purpose; paras 53-54 re context.

181 Libya v Chad, above, 27-28, paras 56-57 re preparatory works; 34-37, paras 66-71 re subsequent attitudes. 
law. ${ }^{182}$ However, it cited only paragraph 1 of the article, stated that "[i]nterpretation must be based above all on the text of the treaty", and agreed that preparatory works and circumstances of conclusion were potential supplementary means. ${ }^{183}$ The Court was therefore not only accepting the general consensus on the articles' status as custom but was also adopting the specifically textualist reading. "Above all on the text" is surely more than the text as the logical "starting point", and the apparent limitation to only article 31(1) is a denial of the "crucible" of means in a unitary process. Not only does this exclude means in paragraphs 2 to 4 intended to be equally important in the mix, it leads as well to a narrowly textual application of the means in paragraph one. This can be demonstrated by reference to the Court's own process of interpretation in this case.

The Court rejects the Libyan interpretation, that article 3 intended only to recognise frontiers already fixed by the previous instruments, as contrary to the "natural and ordinary meaning of the words. ${ }^{184}$ While the Libyan contention is hard to defend, so too is this easy reliance on "natural meaning". The Court no doubt felt they were dealing with an easy case, but to revert to locating "natural" meanings is arguably to resort to fictions.

With respect to object and purpose, it is clear that the Court is limiting itself to locating these from the text of the treaty: One is to "read the 1955 Treaty in the light of its object and purpose". ${ }^{185}$ While this is certainly one important way to discern purpose, it begs the question of whether it is permissible to look elsewhere, to clarify purpose. The Court seems to be implicitly accepting that it is not.

The Court does several times refer to the intention of the parties. ${ }^{186}$ However it is clear that the Court is restricting itself to the Huber formula: it is the "manifest intention", and "the text [which] ... conveys the intention". ${ }^{187}$ Intention, as with the related concept of purpose is relevant to the extent it can be located in the text.

Much of the interpretation analysis concentrates on matters of grammar and semantics: For instance, the meaning and implications of "recognise", the significance of reference to "frontiers", not "the frontier", and the meaning of "en vigueur". ${ }^{188}$ This was probably in

182 Libya $v$ Chad, above, 21, para 41.

183 Libya v Chad, above.

184 Libya v Chad, above, 22, para 43.

185 Libya $v$ Chad, above, 25, para 52.

186 Libya $v$ Chad, above, see for instance, 24, para 48; 25, para 51.

187 Libya $v$ Chad, above, 21, para 41. Emphasis added.

188 Libya v Chad, above, 22, para 42; 23, para 46; 24, para 49. 
part a response to the arguments put to it, especially by Libya, ${ }^{189}$ and is in any case inevitable to some extent, given that the words of the text and their relationships to each other are the logical starting point. However, it can be inferred that the Court was comfortable with this as their principal tool of interpretation, and optimistic about its sufficiency. In this case it no doubt was, but its limitations could easily be exposed in more difficult cases. ${ }^{190}$

The treatment allotted to subsequent practice is illuminating. The Court does not deal with this as a means of interpretation in its primary interpretation of the treaty, or indeed until after it has identified the boundary arising from the annexed conventions. While it details a series of agreements after 1955 and other statements and actions, this is done as an apparently confirmatory analysis of "subsequent attitudes", not practice. ${ }^{191}$ While this may have been due to the way the case was argued, or because the Court did not consider the practice came within the definition in article 31(3)(b), the possibility is not even raised. This again suggests the text trumps other means, even those placed on a par with them, by article 31 .

\section{Separate opinion of Judge Ajibola}

The narrow textual approach of the majority is in contrast to the more wide-ranging interpretation provided by Judge Ajibola. While Judge Ajibola considers the majority "dealt adequately" with the interpretation of article 3,192 he adds a considerably more detailed analysis, highlighting the equal importance of "actual object and purpose", 193 the possibility of an "integration approach" which may help reveal the intentions of the parties, ${ }^{194}$ and the relevance of subsequent practice. ${ }^{195}$ While Judge Ajibola does not come to any different conclusions from the majority, and also seeks to ground his approach in the provisions of articles 31 and 32,196 he demonstrates that it is not necessary or advisable to stop at the text. This once again confirms the ambiguity of the articles. His approach is

189 Libya v Chad, above, 25, para 52.

190 See discussion of Qatar v Bahrain [1995] ICJ 6 below.

191 Libya $v$ Chad, above, 34f, para 66.

192 Libya $v$ Chad, above, 62, para 43, separate opinion of Judge Ajibola. [Libya v Chad, Ajibola J].

193 Libya $v$ Chad, Ajibola J, above200, 62 para 44; 62-66.

194 Libya $v$ Chad, Ajibola J, above, 66-71. The intentions are not being explored directly, but may be revealed by an integrated analysis. The difference between this approach and an examination of the supplementary means, which he does not think is necessary in this case, is not made clear by his Excellency.

195 Libya v Chad, Ajibola J, above, 74-77.

196 Libya $v$ Chad, Ajibola J, above, 62, para 44; 72, paras 88 and 89. 
closer to the crucible advocated by the ILC and further suggests that the textual approach of the Court's judgment will have its limitations when it faces more difficult problems.

\section{Summary: A wrong turn?}

It is unfortunate that the Court chose to define its position on treaty interpretation and the content of articles 31 and 32 in such a straightforward case. The relative ease with which mainly textual analysis resolves the issue in the present case masks that this will not always be so. By adopting the textual approach as mandatory the Court has developed the law without fully testing its implications. It will be seen in the case of Qatar $v$ Bahrain that too-ready reliance on textual analysis can not only lead to inappropriate conclusions, but may also serve as a shield or device, to provide a basis for an interpretation arguably arrived at by other means, or for other reasons.

\section{B Qatar v Bahrain 1995}

\section{Background}

The Case Concerning Maritime Delimitation and Territorial Questions Between Qatar and Bahrain had its roots long before 1971, when the two states gained full independence. ${ }^{197}$ The subject matter concerned land on the Qatar peninsula (Zubarah) claimed by Bahrain, islands off the coast of Qatar held by Bahrain and claimed by Qatar (Hawar Islands and Janan Island), various low tide elevations in the sea between the two states, and the maritime boundaries, once all the territorial claims had been settled. ${ }^{198}$ The Court released its judgment on the substantive case in April 2001, ${ }^{199}$ which is of no special interest for treaty interpretation. The case relevant here is the 1995 Jurisdiction and Admissibility decision, ${ }^{200}$ which turned on a contentious interpretation issue relating to the "international agreements" between Qatar, Bahrain and Saudi Arabia (as neutral mediator) which aimed at settling the dispute by submitting the whole of it to the ICJ. The relevant agreements consisted of identical letters sent by the King of Saudi Arabia in December 1987 to each party, and the so-called "Doha Minutes" of December 1990. The first "agreement" put in train negotiations to conclude a Special Agreement for submission to the Court, which had stalled by late $1988 .^{201}$ The Doha Minutes, the record of a meeting in

197 From their former status as areas under the "protection" of Great Britain.

198 Case Concerning Maritime Delimitation and Territorial Questions Between Qatar and Bahrain [2001] ICJ paras 1-34 available at <www.icj-cij.org/wwwicj/ docket/iqb/iqbframe.htm> (last accessed 3 September 2002). [Qatar v Bahrain 2001]

199 Qatar v Bahrain 2001, above.

200 Qatar v Bahrain 2001, above.

201 Qatar v Bahrain 2001, above, 16, para 29. 
Doha attended by the parties and the King of Saudi Arabia and signed by the parties, agreed critically in paragraph $2:^{202}$

The good offices of ... King Fahd ... shall continue ... to May 1991. Once that period has elapsed the two parties [alternatively 'the parties'] may submit the matter to the International Court of Justice in accordance with the Bahraini formula, which has been accepted by Qatar, and with the procedures consequent on it. The good offices of ... Saudi Arabia will continue during the period the matter is under arbitration.

\section{The issue in 1995}

The critical question for the 1995 case became, did this provision entitle one party to unilaterally refer the dispute to the Court, after May 1991, or would there still need to be either a special agreement or separate but identical applications? ${ }^{203}$

Qatar took the former view, and submitted an application in July 1991. The Court found in July 1994 that the 1987 and 1990 agreements did together constitute international agreements creating binding obligations, by which the parties had undertaken to submit the dispute to the Court. However, as there was as yet only one application, the Court would give the parties opportunity to submit to it "the whole of the dispute". ${ }^{204}$ In the event the parties could not agree on how to do this, and Qatar once again made its own application, which was duly challenged by Bahrain. ${ }^{205}$

\section{The reasoning of the majority}

Thus the Court, having once given the parties another chance to resolve the jurisdiction and seisin issue, was forced to decide whether, based on the earlier agreements it had found, Qatar could in fact unilaterally seise the Court. It found by a majority of 10 to 5 that it could, based on the interpretation it gave to the critical paragraph 2 . It stated that it reached this conclusion "based on the ordinary meaning to be given to [the Minute's] terms in their context and in the light of the object and purpose of the said Minutes". ${ }^{206}$ The Court was clearly once again adopting its minimalist, textual version of Article 31 .

202 Qatar v Bahrain 2001, above, 17, para 30.

203 Qatar v Bahrain 2001, above, 18, para 32.

204 Qatar v Bahrain 2001, above, 9, para 9.

205 Qatar v Bahrain 2001, above, 9-10, paras 12-13. The apparent difference between the parties was how to describe elements of the main dispute: Bahrain insisted on the disputes over Zubarah and the Hawar Islands being described as "claims of sovereignty". In its application Qatar merely noted that this was how Bahrain defined its claim over Zubarah.

206 Qatar v Bahrain 2001, above, 21, para 40. 
Examination of the Court's reasoning shows it overwhelmingly textual, of questionable logic, and inappropriate given the evidence.

The Court began by quoting its summary of the required approach to interpretation from Libya $v$ Chad. ${ }^{207}$ It then looked at the critical expression "al-tarafan" ("the parties or "the two parties"). It acknowledged the ambiguity, over whether this implied joint or unilateral referral, and sought to resolve it by reference to the context in which it was used. ${ }^{208}$ Context is however to be used cautiously; the Court refers to the "more immediate" and "more remote" context, and clearly prefers the former. ${ }^{209}$

The Court relies on the fact that "the two parties may submit ...". It holds that "may" implies, in its most ordinary or natural sense "a possibility or even a right", which therefore suggests an option or right to seise the Court, and to be able to do this unilaterally. ${ }^{210}$ This is an enormous leap in logic. While "may" does suggest possibility rather than obligation, there is nothing in the word or its use to suggest that rights attach severally. It is surely more "natural" to read the words to say that the two parties may submit their case together, or to accept at the very least that the word may does not clarify one way or the other, whether either can or both must. The Court already appears to be drawing unwarranted conclusions from the language used, which are even more dubious when related to the preparatory works, discussed below.

The Court bolsters its conclusion by reference to the phrase "once that period had elapsed", suggesting that the "right" was capable of being exercised as soon as the required five months of mediation had elapsed, which necessarily, for the Court implied the right had to be to unilateral seisin, to be effective. ${ }^{211}$ This is an invocation of the principle of effectiveness, and is driven by the Court's view of the object and purpose of the Doha Minutes: The advancement of the settlement of the dispute by facilitating its referral to the Court. ${ }^{212}$ This is problematic, as Lauterpacht has shown, ${ }^{213}$ as it need not be assumed that the parties, or their agreement had as their object, referral at any cost or by any means. The

207 Libya v Chad [1994] ICJ 6, 21-22, para 41; Qatar v Bahrain 2001, above, 18, para 33.

208 Qatar v Bahrain 2001, above, 18-19, paras 34-36.

209 Qatar v Bahrain 2001, above, 18, para 34. Even the surrounding paragraphs 1 and 3 are seen as "remote".

210 Qatar v Bahrain 2001, above, 18-19, para 35.

211 Qatarv Bahrain 2001, above, 19, para 35.

212 Qatar v Bahrain 2001, above, 19, para 35.

213 H Lauterpacht "Restrictive Interpretations and the Principle of Effectiveness in the Interpretation of Treaties" (1949) 26 BYIL 48, 74. 
principle allows treaties to have appropriate effects, and given the long and difficult negotiating history, where both parties jealously guarded their positions on procedural as well as substantive matters, it is hard to accept that the parties now anticipated unilateral seisin, in the absence of agreement on the issues. The Court is arguably assuming an object and purpose which provides for the greatest effect by the treaty, not necessarily the most appropriate. If the purpose is read less ambitiously, the phrase "once the period has elapsed" does nothing to strengthen any implication of unilateral seisin, but rather merely highlights that no seisin was possible before the new period had expired. While apparently attempting to read words in context, the Court is in reality in danger of amending the treaty.

The Court also relies on the "good offices" provision to reinforce its analysis. It suggests that, as the words might suggest that the intended good offices could not begin again, after the five months, until the matter was in arbitration, and it would be undesirable ("contrary to purpose") to have this mediation suspended, there must have been provision for immediate and unilateral seisin. ${ }^{214}$ The Court appears to recognise this argument is weak, as it stresses that, even if it is wrong on the implications for mediation of the final sentence in paragraph 2 , its earlier reasoning still holds. ${ }^{215}$ While the reasoning here does not therefore carry much weight, it can be seen in any case that it rests again on the purpose assumed by the Court. In any case, it can be argued from the developments in interpretation discussed in section VI below that this is the sort of situation where a court may need to recognise that wrong or infelicitous language has been used, and therefore be slow to accept an implication that may flow from such words. ${ }^{216}$ The wording therefore does not support the Court's conclusion.

To make its conclusion work, the Court has to read down the reference to the "Bahraini formula ... and with the procedures consequent on it". On its face, paragraph 2 indicates any referral must be in accordance with the formula. Arguably, given the context in which the formula was developed in 1988 and the words of its preamble, this would imply joint referral. Such an implication is strengthened by the "and the procedures consequent" stipulation - if the formula anticipated or required joint referral, that would be the procedure required as consequent on it. ${ }^{217}$ The Court dealt with this problem for its conclusion by effectively reading the formula as being used in 1990 to define only the subject matter of the dispute. It justified this by suggesting the formula needed to be

214 Qatar v Bahrain 2001, above, 19, para 36.

215 Qatar v Bahrain 2001, above, 20, para 36.

216 See section VI below, especially Lord Hoffmann's principles, principle IV.

217 Qatar v Bahrain 2001, above, 20, para 37. 
understood in its 1990 context - as a way of settling the subject matter - rather than in its 1988 context. $^{218}$ It therefore managed to suggest that only procedural consequences that survived the change of context were relevant - not the procedural consequences anticipated in 1988 as a result of the formula. 219

The logical and inferential leaps of this reasoning are breathtaking. No evidence - from the text or anywhere else - is presented to support the contention that only the subject matter was being invoked, and the arguable counter-indications in the text are ignored. ${ }^{220}$ The Court appears prepared to do violence to textual analysis, to preserve an interpretation which it favours. While the Court will not consider it is doing so, as it clearly considers it has arrived at the ordinary and "clear" meaning of the text, the situation does show the inherent limitations of the textual approach as a method, and therefore as the purpose of interpretation: The text is at best ambiguous or contradictory, if viewed from the Court's perspective, and cannot be a complete answer to the interpretation question - even with the aid of treaty purpose, inferred from the text.

The interpretation is in fact so tenuous that it suggests the Court may have merely been using textual devices to achieve an end it saw as desirable for other reasons, just as Lauterpacht had suggested Courts could and did, when applying "rules". ${ }^{221}$ It can be argued here that what the Court is achieving is what it sees as the equitable and desirable result, despite the difficulties with interpretation: desirable as it should help to move toward settlement an intractable dispute which has the potential for violence; equitable because while it allows Qatar to achieve unilateral seisin, it does so in a format which broadly meets apparent Bahraini concerns over subject matter, and allows the Court to specifically state that the remaining concerns, specifically claims of sovereignty, will fall within the dispute. ${ }^{222}$ While there is no direct appeal to equity, it is difficult to escape the conclusion that the Court felt it was achieving a "fair" result, and that its approach to interpretation could support that. ${ }^{223}$ The willingness to go to the fair result points to the conceptual poverty of the majority's approach to interpretation, which is drawn out in the dissenting opinions discussed below, and will be commented on further in section VI.

218 Qatar v Bahrain 2001, above, 20, para 38.

219 Qatar v Bahrain 2001, above, 21, para 39.

220 Qatarv Bahrain 2001, above, 20, para 38.

$221 \mathrm{H}$ Lauterpacht "Restrictive Interpretations and the Principle of Effectiveness in the Interpretation of Treaties" (1949) 26 BYIL 48, 53.

222 Qatar v Bahrain 2001, above, 25, paras 47-48.

223 This is arguably the opposite to the conclusion of Ajibola J's separate opinion in Libya $v$ Chad [1994] ICJ 6, 59, para 29, that equity has no role to play when a treaty decides a matter. 
Despite all the interpretative difficulties it has picked its way through, the Court considers that it has arrived at a satisfactory ordinary meaning in terms of article 31(1), and that therefore reference to supplementary means is therefore strictly unnecessary. ${ }^{224}$ Although it goes on to consider preparatory works, to help confirm its conclusions, ${ }^{225}$ the Court's position implies a very narrow view of the role of such means. The Court apparently considers that, despite the evident ambiguity, it has been resolved and the meaning is not left "ambiguous or obscure", 226 meaning reference is not required. It would seem far better, and in keeping with a reasonable textual approach, to have recognised that while the Court preferred one meaning, ambiguity remained, and other sources could and should be used to resolve it.

The Court's treatment of the preparatory works is unconvincing and misconceived. It approaches them with caution because of their "fragmentary" nature, ${ }^{227}$ but does note the crucial fact that an earlier draft of paragraph two provided "either of the two parties", but that this was removed at the insistence of Bahrain. ${ }^{228}$ While noting this earlier version would clearly have provided for unilateral seisin, the Court argued that its removal does not demonstrate the opposite conclusion. ${ }^{229}$ While this may be arguable from a strictly logical viewpoint, it is surely contrary to a textual approach to argue that a change in wording does not mean something. Even more importantly, given that preparatory works are used to establish the intention of the parties when it is not otherwise evident, ${ }^{230}$ it must be concluded that, either the parties did not agree or commonly intend unilateral seisin, or at least that Bahrain did not so intend, and at the very least Qatar ought to have known this. The requirement for interpretation in good faith should surely mean that Qatar could not rely on its "interpretation". Alternatively, it will be argued in the final section, this change should be taken to indicate, either that the parties had agreed a "special meaning" for al -tarafan, or that the "objective" intention of the parties was that unilateral seisin be

224 Qatar v Bahrain 2001, above, 21, para 40.

225 The Court was no doubt aware that the minority judges would have much to say about the preparatory works and their significance, making discussion of them practically unavoidable, even if they regarded this as theoretically unnecessary.

226 Vienna Convention, Article 32(a).

227 Qatar v Bahrain 2001, above, 21, para 40.

228 Qatar v Bahrain 2001, above.

229 Qatar v Bahrain 2001, above.

230 See Sir H Waldock Third Report of the Special Rapporteur on the Law of Treaties to the ILC (1964) YBILC II; G G Fitzmaurice "The Law and Procedure of the International Court of Justice, 1951-4: Treaty Interpretation and other Treaty Points" (1957) 33 BYIL 203, principle IV, and 211. 
excluded. Whichever method is adopted, it is submitted that the Court's failure to give any weight at all is unsustainable.

\section{Dissenting opinions}

Not surprisingly, the Court's judgment was subject to vigorous dissent. Not all of the five dissenters concentrated on the interpretation weaknesses. ${ }^{231}$ However, Judge Shahabuddeen pointed out the weakness of the Court's reading down of the reference to the Bahraini formula, ${ }^{232}$ and he and others pointed to the real difficulties with the Court's analysis of the preparatory works, and the earlier version of "either of the parties". ${ }^{233}$ Interestingly, Judge Shahabuddeen was prepared to say the meaning of the text was "clear", 234 on the basis of his reading of the reference to the formula. This demonstrates the unavoidable shortcoming of the textual approach: different readers will often arrive at quite different, often directly opposed but allegedly "clear" meanings. Surely the better position is to accept that "clear" meanings are too frequently illusory, and that it will be better to accept the prevalence of ambiguity, and use all available means find what can often only be the "most likely" or "most appropriate" meaning in the circumstances.

It is not altogether clear that the dissenting judges all want to severely qualify the textual approach of the majority, although all are prepared to use a wider range of means to resolve the central ambiguity. Vice President Schwebel however goes much further, and brings the debate back to the fundamental issue of the true basis or purpose of interpretation. He first refers to Lord McNair to establish that the ultimate goal is to give effect to the intention of the parties, that is, in Schwebel's words "the common intention of both parties". ${ }^{235} \mathrm{He}$ then refers to numerous passages from the ILC proceedings to demonstrate the importance of establishing intentions, and the utility of preparatory works for doing so. ${ }^{236} \mathrm{He}$ also points out that no-one in the case had even questioned the resort to preparatory works, or criticised them as "fragmentary, inconclusive, or otherwise open to

231 Qatar v Bahrain 2001, above, 40-50, dissenting opinion of Judge Oda, who relied mainly on criticisms of the Courts approach to jurisdiction, and the doubtful nature of what he referred to as the "agreements".

232 Qatar v Bahrain 2001, above, 56, dissenting opinion of Judge Shahabuddeen.

233 Qatar v Bahrain 2001, above, 56-58, dissenting opinion of Judge Shahabuddeen; 34-37, dissenting opinion of Judge Schwebel; 69, dissenting opinion of Judge Koroma; 76, dissenting opinion of Judge ad hoc Valticos.

234 Qatar v Bahrain 2001, above, 56, dissenting opinion of Judge Shahabuddeen.

235 Qatar v Bahrain 2001, above, 27 dissenting opinion of Vice President Schwebel [Qatar v Bahrain 2001, Schwebel]; Lord McNair The Law of Treaties (2 ed, Oxford University Press, Oxford, 1961) 364,366 .

236 Qatar v Bahrain 2001, Schwebel, above, 28-32. 
discounting or disregard". ${ }^{237}$ His central point is that all methods of interpretation, including textual analysis, should have as their central aim the finding of and giving effect to actual joint intentions. Nothing which assists in this should be neglected, and limitations which get in the way of it are inappropriate. In drawing so heavily on the ILC, he also appears to be implicitly assuming that this approach is consistent with articles 31 and 32 .

It is significant that for Schwebel, it is enough that examination of the preparatory works demonstrates that unilateral seisin cannot have been a "common" intention. ${ }^{238}$ This shows the object of the Minutes cannot have been to allow unilateral seisin, as there could be no such purpose without common intention. The Court's interpretation therefore falls outside the Vienna Convention rules, as it cannot be "in good faith". ${ }^{239}$ Thus, the analysis helps to demonstrate that the intentions of the parties can be relevant, even where they are not common, at least in a negative way. While this does not completely remove the objection to the intentions school, that giving effect to intentions often means making them up, it does confirm that actual common intentions should be decisive, and that even where they are absent, an understanding of what intentions there are can still be of assistance. The scope for re-integrating intentions back into the process of interpretation will be discussed further in section VI.

\section{Summary}

Qatar $v$ Bahrain not only demonstrates limitations and dangers in the regime for interpretation espoused in Libya $v$ Chad. it also suggests some lines of enquiry to effect corrections. It is likely that such corrections will include establishing a clearer and agreed basis for interpretation, and allowing the appropriate recognition of the intentions of the parties, whether common or divergent. It is submitted that such corrections are far more likely to provide certainty in interpretation, than the approach of the majority in this case, which can best be described as arbitrary. ${ }^{240}$

237 Qatar v Bahrain 2001, Schwebel, above, 32.

238 Qatar v Bahrain 2001, Schwebel, above, 35.

239 Qatar v Bahrain 2001, Schwebel, above, 36.

240 Problems with interpretation have not stopped with Qatar v Bahrain [2001] ICJ. See P R McRae "The Search for Meaning" (Unpublished Masters Research paper, Victoria University of Wellington, 2001) for an analysis of Case concerning Kasikili/Sedudu Island (Botswana/Namibia) [1999] ICJ 6, para 21, <www.icj-cij.org/cijwww/cij/ccases/cbona/cbonabanner.htm> (last accessed 24 May 2001) [Kasikili Island]. This case shows continuing divergence of views in the ICJ over what interpretation can and cannot achieve, and when and how it should be used. 
As disagreements over interpretation seem likely to continue, it is now timely to see whether the opposing approaches can be integrated to form a more viable process. Modern thinking about the approach to contract interpretation can help show one possible solution.

\section{THE MODERN THEORY OF CONTRACT INTERPRETATION, AND TREATIES}

It is permissible and sensible to look to commercial contract law for answers on this subject. While the subject matter of treaties and commercial contracts are vastly different, they are both laid on the same foundation of consensual agreement to be bound to legal obligations. Given the consensual basis of all International Law, and especially of Treaty Law, it is logical to look to a parallel system equally based on voluntary assumption of obligations requiring a meeting of minds. Furthermore, it is evident that the law of treaty interpretation has frequently "borrow[ed] ... from the private law of contract". ${ }^{241}$ This has usually been to gather logical maxims and tools of interpretation, such as ejusdem generis or a contrario, which are of course not legal rules. ${ }^{242}$ However, this does not destroy the power of the analogy. Contract law would no doubt agree with international, that these are useful guides, not rules of law. More importantly, if contract law has faced the same controversies, over the dominance of "plain meaning", and the relative weight and admissibility of different types of evidence, ${ }^{243}$ and has found better ways to resolve them, then it is surely sensible for interpreters of treaties to see what can be transmitted from interpretation of contracts.

\section{A The Plain Meaning Rule and Emerging Ideas}

Anglo-Saxon, and especially British Commonwealth, contract law has traditionally held to a "Plain Meaning Rule" of contract interpretation. The parallels with the classic textual position in treaty interpretation can be seen in a New Zealand expression of the rule: ${ }^{244}$

[W] here words or a clause or indeed a contract as a whole have a clear objectively ascertainable meaning on the face of the document, then that is the meaning which the parties will be held to have intended and to which they shall be bound ... On the other hand where a

241 Lord McNair The Law of Treaties (2 ed, Oxford University Press, Oxford, 1961) 364.

242 Sir H Waldock Third Report of the Special Rapporteur on the Law of Treaties to the ILC (1964) YBILC II, 54, para 6; ILC Commentary (1964) II YBILC, above, 200, para 5.

243 See generally D McLauchlan "The Plain Meaning Rule of Contract Interpretation" (1996) 2 NZBLQ 80 , for both background on the contract interpretation debates, and his proposed resolution.

244 Benjamin Developments Ltd v Robert Jones (Pacific) Ltd [1994] 3 NZLR 189, 207 (CA) Gallen J. 
word or a clause or indeed a whole contract is ambiguous or the result of a literal construction gives rise objectively to ambiguity or absurdity then the authorities allow the true intention to be elucidated by the admission of evidence directed to that end.

Thus, while as with treaties under the textual approach, the intentions of the parties are theoretically important, a "clear", "plain" or "ordinary" meaning in the context of the contract, may give rise to an unrebuttable presumption that that is what the parties intended, and any diverging actual intention is irrelevant. In this strict form, extrinsic evidence may not be admitted to demonstrate the ambiguity or absurdity, if it is not apparent on the face. ${ }^{245}$

Such a stern view is usually justified by its defenders on the basis of certainty, the need for objectivity, and reasons of convenience or expedience. ${ }^{246}$ Such arguments have drawn criticism when used in defence of textualism in treaty interpretation, and the Plain Meaning Rule has been subject to vigorous academic criticism, ${ }^{247}$ and judicial retreat, to the extent that it can probably no longer be said to represent the law in the United Kingdom or New Zealand. ${ }^{248}$

Professor McLauchlan bases his critique on a more realistic understanding of the uncertainty of language, the narrow scope and lack of legal quality in the so-called parol evidence rule, and a more cautious approach to the objective theory of contract. ${ }^{249}$ While the parol evidence rule, which states that recourse to extrinsic evidence is impermissible if it would contradict, add to, or vary an apparently complete written contract, ${ }^{250}$ can be

245 Benjamin Developments, above, 203, Hardie Boys J.

246 Masport Ltd v Morrison Industries Ltd (31 August 1993) Court of Appeal, Wellington, CA 362/92, Cooke P; B \& B Constructions (Aust) Pty Ltd v Cheeseman and Assocs Pty Ltd (1994) 35 NSWLR 227, 234 (NSWSC) Kirby P; see also McLauchlan, above, 98-99.

247 McLauchlan, above; see also A L Corbin Corbin on Contracts (1 rev ed, St Paul, West Publishing, 1960) vol 3, ch 24, and A L Corbin "The Interpretation of Words and the Parol Evidence Rule" (1965) 50 Cornell LQ 161, which McLauchlan refers to extensively.

248 Investors Compensation Scheme v W Bromwich Building Society [1998] 1 WLR 896, 906ff (HL) Lord Hoffmannn; Boat Park v Hutchinson [1999] 2 NZLR 74 (CA); but note Melanesian Mission Trust Board v AMP Society [1997] 1 NZLR 391 (PC), which arguably preserves the plain meaning approach adopted in Benjamin Developments Ltd v Robert Jones (Pacific) Ltd [1994] 3 NZLR 189 (CA).

249 McLauchlan, above, 81.

250 McLauchlan, above, 87; see also D McLauchlan "The Admissibility of Parol Evidence to Interpret Written Contracts" (1974) 6 NZULR 121. 
treated as peculiar to contract law, and never part of the International Law of Treaties, ${ }^{251}$ the other two factors can be seen as highly relevant to interpretation of treaties.

Professor McLauchlan asserts, with Corbin, Holmes and others, ${ }^{252}$ that it is a mistake to regard words as having "fixed" or "natural" meaning, but rather they are given meaning by the hearer or reader, or by the speaker or writer. ${ }^{253}$ It follows that it is possible, indeed desirable, to select the meaning the parties actually attached to the words used, or where they attached different meanings, that meaning which was held by one party and known to the other, rather than the apparently "plain" but different meaning contained in a document. ${ }^{254}$ This is not to deny that words and phrases will often have apparently plain or ordinary meanings. Where they do, this will be strong, but not conclusive evidence that this was the meaning adopted by the parties. But where there is convincing evidence that the parties actually meant something else, why should a court hold them to a meaning that neither intended? ${ }^{255}$ In treaty terms, such would be contrary to pacta sunt servanda and good faith.

The need to move away from a too ready acceptance of a "plain" meaning has been recognised by the courts, in particular in the shape of five principles developed by Lord Hoffmann in the ICS case. ${ }^{256}$ The principles hold that it is always appropriate to consider all the relevant background, when seeking to arrive, objectively, at the meaning of a document, that is, whether or not there is any apparent ambiguity. The relevant background is very widely defined, except for Lord Hoffmann it still does not include the negotiations of the parties, or their declarations of subjective intent. It is important that the focus be on documents, not words: In some cases the background may actually establish that, for some reason, the parties used the wrong words or syntax. The plain meaning rule is therefore reduced to an evidentiary presumption, that we do not lightly accept that

251 See for instance the Vienna Convention, Article 31(3), re subsequent agreement or practice, which must be regarded as extrinsic evidence.

252 McLauchlan, above, 84.

253 This insight clearly goes further than the recognition, even by the textualists of the ILC, that words only have ordinary meaning in context. It shows that the apparent meaning, even in context may not be the actual meaning, thus undermining the purely textual approach.

254 McLauchlan, above, 85.

255 McLauchlan, above, 87.

256 Investors Compensation Scheme v West Bromwich Building Society [1998] 1 WLR 896 (HL). 
parties have made linguistic mistakes, or that for some other reason, the apparent meaning is not in fact the meaning of the parties. 257

The Hoffmann principles establish the first part of Professor McLauchlan's thesis, that an apparently plain meaning is rebuttable by other evidence. They continue to rely on an objective theory however, that objective not actual intentions of the parties are what is being sought. ${ }^{258}$ As Professor McLauchlan has pointed out, ${ }^{259}$ such reluctance is not reflected outside the British Commonwealth. The American Restatement provides for interpretation according to the actual common intention, or where intentions diverge, the intention of one party when the other party knew or ought to have known of it. ${ }^{260}$ This position is also adopted in the United Nations Convention on Contracts for the International Sale of Goods, ${ }^{261}$ and in the Unidroit Principles of International Commercial Contracts, effectively a restatement of the commercial contract law of the world. ${ }^{262}$ The common sense position, that we should interpret in accordance with the actual intentions of the parties when we know them, and not limit our resources when trying to establish such intention, is therefore increasingly widely accepted on an international level, at least in respect of contracts. This begs the question, why a similar approach should not apply with treaties, where the emphasis on consent of the parties is arguably even stronger.

It should be pointed out that this position is not in reality a retreat to subjectivity. While that which is being referred to can be described as the "subjective intentions of the parties", it is just as easily and more accurately described as their "actual intentions".263 Any alleged actual intention has to be subject to objective evidence. Interpreters do not

257 Investors Compensation Scheme, above, 912-913, Lord Hoffmann. The principles were adopted, in shortened form, by the New Zealand Court of Appeal in Boat Park $v$ Hutchinson [1999] 2 NZLR 74 (CA).

258 Although doubt is cast upon this restriction by more recent cases which accept the parties' subsequent conduct as evidence: see Attorney General v Dreux Holdings (1996) TCLR 617 (CA); D McLauchlan "Subsequent Conduct and Contract Interpretation: An Update" (1997) 3 NZBLQ 147.

259 D McLauchlan "The Plain Meaning Rule of Contract Interpretation" (1996) 2 NZBLQ 80.

260 American Law Institute Restatement (Second) of the Law of Contract (St Paul Minneapolis, American law Institute, 1981) § 201.

261 UNCITRAL United Nations Convention on Contracts for the International Sale of Goods, Doc (1987) 52 No 40 US Federal Register 6262, 6266, Article 8.

262 UNIDROIT Unidroit Principles of International Commercial Contracts (1994) Articles 4.1-4.3; McLauchlan, above, 98; J Perillo "Unidroit Principles of International Commercial Contracts: The Black Letter Text and a Review" (1994) 63 Fordham L Rev 281, 283.

263 McLauchlan, above, 93. 
need to delve into "unfathomable depths of subjective intentions". ${ }^{264}$ Rather they will need to consider what reliable evidence (more than mere assertion) is available to point to intention. It can be said that the label "subjective" is more an epithet useful to cast doubt on a necessary enquiry, than it is a statement of any real objection.

\section{B Implications for Treaty Interpretation: A Synthesis?}

The law of treaty interpretation has not been so restrictive as the strict form of the Plain Meaning Rule, described above, at least since the codification of articles 31 and 32. Article 31 not only allows, but according to the ILC requires resort to extrinsic evidence, through paragraph 31(3) and presumably paragraph (4). ${ }^{265}$ It is clear from the ILC Commentary and article 31 itself that the primary recourse to subsequent practice is limited to concordant practice. Such recourse cannot logically be denied, as it represents a consensual agreement of the law. ${ }^{266}$ However the provision at least avoids the blanket ban which the Plain Meaning Rule imposes, and confirms that in this fact situation at least the actual intentions of the parties - what they agreed - should be decisive. It is notable that the Court, in Kasikili Island clearly felt obliged to examine subsequent practice, even though it considered it had found the ordinary meaning. ${ }^{267}$ The unavoidable inference is that common intentions can and should be decisive, even potentially when they may appear to contradict an apparent "ordinary meaning". Similarly, while the ILC considered resort to a special meaning was likely to be rare, and the textualists argued that the special meaning would or should appear as the ordinary meaning from the text or context, ${ }^{268}$ it was recognised by others that it would be impossible to establish special meanings without recourse to extrinsic means. ${ }^{269}$ The decision to keep the "special meaning" provision in article 31, rather than placing it as a subordinate or supplementary article, or deleting it altogether, implies an acceptance that an actual common agreement on meaning should be determinative, when it can be proven. Thus article 31 is not a strict plain meaning rule, despite the apparent attitude of the Court, in Libya $v$ Chad, and Qatar v Bahrain.

264 B \& B Constructions (Aust) Pty Ltd $v$ Cheeseman and Assocs Pty Ltd (1994) 35 NSWLR 227 (NSWSC).

265 Report of the International Law Commission on Draft Articles (1966) II YBILC 220, para 8. [ILC Commentary 1966]

266 ILC Commentary 1966, above, 222, para 15; Vienna Convention, Article 31(3)(b). Non-concordant practice is merely another type of supplementary means, to which there may or may not be recourse.

267 Case concerning Kasikili/Sedudu Island (Botswana/Namibia) [1999] ICJ 6, para 53ff, <www.icjcij.org/cijwww/cij/ccases/cbona/cbonabanner.htm> (last accessed 24 May 2001). [Kasikili Island]

268 ILC Proceedings (1966) I Pt II 98, para 3, Sir H Waldock. [ILC Proceedings 1966]

269 ILC Proceedings 1966, above, 205, para 24, Mr Ago. 
Despite this potential permissiveness, treaty interpretation can still learn and adopt much from the emerging modern understanding of contract interpretation. The old contest between text and intentions can be resolved, not by enshrining one view or the other, but by according each its appropriate place. Treaty interpretation should no longer be seen as a field of battle between two main but opposing schools of thought, but rather as an area of broad enquiry, where insights from the schools can be brought into harmony, so that each supports an ultimate goal, of more certain interpretations which are the most likely to be in accordance with the will of the parties.

It is submitted that we should accept that the goal or object of treaty interpretation, is to give effect to the intentions of the parties. ${ }^{270}$ This means that, while we can still accept Judge Huber's precept, ${ }^{271}$ at least as a rebuttable presumption of fact, an apparently plain or ordinary meaning will merely be strong evidence that that is the meaning the parties intended. ${ }^{272}$ If, however, some other evidence offers convincing proof that the actual intention of the parties requires a different meaning or result, then that meaning should be preferred, in accordance with the basic purpose, and to comply with considerations of good faith. Thus, the text remains the starting point but not necessarily the determinant of analysis.

This approach may in some circumstances lead to a special meaning in terms of article 31(4), but it will be wider than that limited or special case. For instance, it may be necessary or possible to give a word or phrase a particular interpretation, to accord with the known overall actual intention of the parties, even though the parties never turned their mind to the meaning of the particular words, or how they should be interpreted in a new, previously unforeseen situation. There will no doubt continue to be numerous situations where the ascertainable intentions of the parties add nothing, or are irrelevant because the parties have simply not turned their minds to the possibility which has subsequently arisen, and this case is dealt with below. However, the intentions of the parties may still in some cases cast light, at least by inference, on how an unforeseen problem or circumstance should be approached, and it would once again be contrary to good faith to ignore any such insight.

There will also be the situation highlighted by Lord Hoffmann, where the parties had a clear intention, but inadvertently used wrong or misleading words or syntax. ${ }^{273}$ An

270 In one sense this contention is not even controversial: The textualist merely translates it to presume that intention is normally as expressed in the text.

271 M Huber (1952) 44 Annuaire de l'Institut de droit international 199.

272 See Investors Compensation Scheme v W Bromwich Building Society [1998] 1 WLR 896, 913 E (HL) Lord Hoffmann, Principle V.

273 Investors Compensation Scheme, above, 913 D, Lord Hoffmann, Principle IV. 
example of such a situation is provided in Qatar $v$ Bahrain, and gives the answer to the majority's somewhat strained attempt to support its main reasoning by reference to the words relating to the continuation of Saudi Arabia's "good offices". ${ }^{274}$ It is surely an unwarranted inference, to insist on a literal interpretation of some ancillary but poorly worded or conceived phrase, thus affecting the interpretation of more central treaty provisions, when it is clear from the context or other clues that the parties' intentions were quite contrary to such an interpretation. Arguably, Lord Hoffmann's recognition that we sometimes do not have to, or cannot give a meaning or a consistent interpretation to every word used, is the key to unlocking overly formalistic approaches to interpretation, and thus arriving at the most appropriate understanding of a treaty. Finally, It may often be a case of choosing between two or more potential meanings, each of which could be the "ordinary meaning", based on which better fulfils the intentions of the parties. Once again, this can be argued to be the situation the Court faced (but attacked rather differently) in Qatar $v$ Bahrain, when dealing with al-tarafan, and the related words. ${ }^{275}$

In some circumstances it may be clear that, while it cannot be established that both parties shared the same intention, one party intended a particular meaning, and this intention was known to the other. Following the contract principles, this meaning should be taken to be the objective intention of the parties. If only by silence, a party may have reasonably led the other to believe that their meaning was accepted, and should not later be able to argue a different meaning. It might be argued this approach diverges somewhat from the consensual basis of international law: One party's intended meaning is being favoured, not the meaning consensually agreed between the two. However it is submitted that such a response is in fact both permissible and required. To allow a party to resile from a meaning they can be argued to have tacitly accepted, or at least by omission encouraged another party to believe they accepted, would not only be contrary to the objective theory, in contract terms, but would also be contrary to the obligation of good faith, in treaty terms. Such a result would be destructive of pacta sunt servanda, and encourages exactly the kind of unreasonable result reached in Qatar $v$ Bahrain. ${ }^{276}$ In any case, there is surely a good evidentiary case accepting that a party accepts or agrees to a meaning placed on a provision by another party, if they know the meaning which is being ascribed, and take no action to dispute it. At the very least this is strong objective evidence that such a known meaning is in fact the one intended by the parties.

274 Case Concerning Maritime Delimitation and Territorial Questions Between Qatar and Bahrain [2001] ICJ para 19, para 36, available at <www.icj-cij.org/wwwicj/ docket/iqb/iqbframe.htm> (last accessed 3 September 2002) [Qatar $v$ Bahrain 2001]. See discussion of majority's reasoning above part V.

275 Qatar v Bahrain 2001, above, 18-19. See part V.

276 Qatar v Bahrain 2001, above, 35, dissenting opinion of Vice President Schwebel. 
If no common intention can be established, for any of the five reasons given by Lauterpacht, ${ }^{277}$ then it is submitted the most reasonable meaning based on all the circumstances should be chosen. In such a situation, the words of the text, in context, may in fact be all that the interpreter has to work with, and in any case will carry very strong evidentiary value. Given the large number of cases, where parties simply will not have turned their mind to an issue, or where new circumstances arise, and common intentions which are known cast no light, this may well remain the most common situation. The above approach, however, simply adds to this normal situation, that the interpreter should not ignore the actual or objective (as opposed to implied or presumed) intentions of the parties, where these are available or can be ascertained by enquiry. Just because a textual or contextual enquiry will sometimes, even often, be all that is realistically available to the interpreter, this provides no justification for ignoring other or stronger evidence of the will of the parties, where it is available.

The natural corollary of this approach is that no potential source of evidence should be excluded if it will provide proof of intentions and therefore, the parties' meaning. The relative weight of different types of evidence will still need to be considered, and it will of course take clear contradictory evidence to overturn an apparently clear meaning.

It must be emphasised that the approach just suggested above is not the replacement of the textual approach with the intentions of the parties school. It does not require or allow resort to "implied intentions" to fill every gap left in the actual intentions of the parties. Where common or objective intention is not ascertainable, there is no benefit in choosing a meaning, and then attributing that as the supposed intention of the parties. It is surely far better to recognise that intention can only go so far, and that where it does not assist, we should look for the most reasonable interpretation.

\section{Merits of the Proposed Approach}

It is submitted that the above approach is more consistent with the basic principles of pacta sunt servanda, and interpretation in good faith, than either the textual or the thoroughgoing intentions approach. It seems beyond argument that good faith requires us to choose an interpretation which we know represents the will of the parties, over one which can be justified only by a purely linguistic analysis as an ordinary meaning. Similarly, the limitations on intentions, to prevent them being created by the interpreter to fill gaps, reinforces the focus on the treaty itself - and the will of the parties - rather than on the mind of the interpreter.

277 H Lauterpacht "Restrictive Interpretations and the Principle of Effectiveness in the Interpretation of Treaties" (1949) 26 BYIL 48, 79. 
This approach should help avoid at least some arbitrary or unjustified interpretations, and assist interpreters to arrive more readily at agreed interpretations. Reference to the cases discussed in section $\mathrm{V}$ above is instructive. In Libya $v$ Chad, the above approach would probably have made no difference to the result. The textual and extrinsic evidence both led to the same conclusion, that is that the parties did intend to fix the border, and did so according to the 1919 Franco-British Agreement. ${ }^{278}$ By contrast, it is submitted that it would have been impossible for the majority to reach the same conclusion in Qatar $v$ Bahrain. Given the evidence of the preparatory works, it would surely have been difficult to avoid the conclusion either that the parties did share a common intention, that unilateral seisin was not permitted, or alternatively that Bahrain held such a view, which must have been obvious to Qatar when it agreed to the revised wording. ${ }^{279}$ The Court would arguably have been prevented or at least discouraged from adopting a strained and unconvincing semantic analysis, to justify the conclusion it apparently wished to arrive at, and Qatar would have been precluded in good faith from maintaining the interpretation which the majority ultimately accepted.

The above brief survey suggests that the approach suggested can make a useful contribution to courts' and tribunal's interpretative efforts. Judges will be less tempted or able to use textual analysis to achieve interpretations seen as desirable for other reasons. Also, given the prevalence of ambiguity recognised by the modern contract-based approach, judges will not be forced to resort to devices, merely to justify use of evidence they consider relevant. The current frequent or habitual recourse to preparatory works 280 will be regularised, by both the need to check for evidence of actual intentions, and the admission that ambiguity is the norm.

As an ancillary benefit, we can speculate that a closer approximation between the processes of contract and treaty interpretation will bring us closer to a more coherent general understanding of how legal documents are to be interpreted. While it is not surprising that different areas of law have developed different rules, the law will be more comprehensible and defensible, if common issues are tackled in consistent ways.

278 Libya v Chad [1994] ICJ 6, 26-27, paras 55-56.

279 Qatar v Bahrain above, 35, dissenting opinion of Vice-President Schwebel; compare 21-23 para 41, judgment of the Court.

280 See R Gardiner "Treaties and Treaty Materials: Role, Relevance and Accessibility" (1997) 46 ICLQ 643. 
Against these logical and procedural advantages, it could be argued that any change would be at the price of certainty. ${ }^{281}$ Location of actual intentions may be seen to be more difficult, less certain, and less predictable than merely reading a text. Against this, it has been pointed out above, and Qatar $v$ Bahrain confirms, that text can be at least as slippery as intentions, and just as open to abuse. Arguably, if an actual intention can be located, then the interpretation is the most certain of all those possible. Given that fictions such as "presumed" or "implied" intention are eschewed, there is nothing to suggest that the modern contract approach is any less certain than that which it would modify. The opposite is more likely to be the case.

Policy arguments of convenience and efficiency have been raised against the modern contract approach. It is submitted with Professor McLauchlan, ${ }^{282}$ that these are unconvincing. In international cases, the reality is that recourse to preparatory works is normal. ${ }^{283}$ If resort to preparatory works is inevitable, then adoption of the modern contract approach will make their use more rational, and is hardly likely to require significant further time or resource than is already expended. If the enquiry is more focused on seeking to reveal what the parties intended, rather than simply hunting for evidence which might somehow help to support an interpretation favoured by one party or another, then disputes may actually be resolved more efficiently. In any case, every time resort to the most appropriate or convincing evidence leads to an interpretation reflecting the actual intention of the parties, a more effective - and therefore more efficient in the long run - result should be achieved. The modern contract or "actual intentions" approach should promote efficiency, not impede it.

All of the above suggests that the proposed approach is logical, more likely to promote appropriate results, and is likely to be as efficient as the current textual orthodoxy. One crucial criticism which must however be addressed, is whether such an approach is permissible within the law provided by articles 31 and 32. There is little point advocating a system, if it would require revision of the treaty - surely an unlikely event. Is the proposed approach consistent with the Convention provisions?

281 F Jacobs "Varieties of Approach to Treaty Interpretation: with Special Reference to the Draft Convention on the Law of Treaties Before the Vienna Diplomatic Conference" (1969) 18 ICLQ 318, 342-343.

282 D McLauchlan "The Plain Meaning Rule of Contract Interpretation" (1996) 2 NZBLQ 80, 98-100.

283 Gardiner, above. 


\section{The Modern Contract Approach and Articles 31 and 32}

The articles are silent on the purpose or basis of treaty interpretation, perhaps because the drafters chose to leave the matter, to avoid the doctrinal conflicts. ${ }^{284}$ As this implies an absence of common intention, the purpose proposed should be permissible - that is, not proscribed - so long as it is consistent with what is provided in the articles and is the most reasonable purpose. It is surely unreasonable to suggest that treaty interpretation has or needs no purpose, meaning that some purpose must be able to be inferred.

It is submitted that the requirement for interpretation in good faith favours the purpose and approach argued for. Not to give effect to the will of the parties, when it is known or knowable, cuts across good faith. It is difficult to envisage any other purpose - for instance such as to give effect to or elucidate the meaning of the text - which is able to satisfy the good faith requirement.

Although intention is mentioned only in one paragraph, 285 it can be seen as inherent in both the concept of object and purpose, ${ }^{286}$ and is the reason for reference to preparatory works in the first place. ${ }^{287}$ Further, the relevance of the intentions of the parties is confirmed, both in article 31(3)(a) and (b), and in 31(4). Paragraph 4 is particularly compelling of the view that an established actual intention takes precedence. All the modern contract insights are adding, therefore, is a logical extension or conclusion, showing the importance or determinative quality of intentions, where they can be established. The articles already accept, as did their drafters, that the intentions of the parties are relevant. It is therefore the task of the interpreter to discover intentions when this is possible, and therefore to give effect to them.

It must be recalled that the ILC intended the process of interpretation to be a unity, with all methods thrown in the crucible. ${ }^{288}$ Such an approach is far more consistent with giving preference to actual common intention, than it is with insisting on the primacy of text, especially when several of the elements rely on, or seek to locate, an actual intention. In fact, the explicit denial of any hierarchy, and the relegation of the text to the "starting point", 289 confirms that text and ordinary meaning are one of several means to an end, not

284 See part III above.

285 Vienna Convention, Article 31(4).

286 Sir I Sinclair The Vienna Convention on the Law of Treaties (2 ed, Manchester University Press, Manchester, 1984) 130. But note Sinclair's own contrary view.

287 Sir H Waldock Third Report of the Special Rapporteur on the Law of Treaties to the ILC (1964) YBILC II 5, 58, para 20.

288 See part III above.

289 See part III above. 
the end itself. The most appropriate conclusion is that article 31 is consistent with, where possible, finding the actual intention of the parties.

It is true that article 32 appears to relegate preparatory works to a subordinate position, apparently inconsistent with using the widest possible means to arrive at actual intention. It is clear, however, the ILC, in fact, intended wide or liberal recourse to the "supplementary means". ${ }^{290}$ Given the purpose of such access, to provide insight into intentions, the scheme of article 32 also supports interpretation according to the actual common intention of the parties.

It is submitted that, as the articles were themselves originally a complex compromise, the proposed "actual or objective intentions, otherwise the most reasonable interpretation" approach is both consistent with the articles, and a better reflection of them than a reading which emphasises the primacy of the text or ordinary meaning. The proposed approach gives both intentions and the words of the text their proper weight in resolving interpretations, with each likely to be determinative in different circumstances. This in itself is a compromise, but one which is consistent with both the text and the intentions of the drafters, as far as they went, and is also logically defensible, and likely to lead to reasonable results.

\section{E Summary: A New Way Forward?}

The above analysis suggests that there are no impediments, and clear advantages, to adopting the insights to be gained from the modern contract approach to interpretation. While the approach suggested can fairly be said to be rather different from the textualist orthodoxy which has emerged in recent years, it does not deny the importance of text, is arguably close to and consistent with the original intentions of the drafters, and is far more likely to resolve arguments over interpretation which clearly still persist, at least at World Court level. It is to be hoped that widening acceptance of this modern contract approach will influence the approach which jurists and practitioners take in future to treaty interpretation.

\section{CONCLUSION}

I have argued that treaty interpretation has continued to be a source of controversy, because we have not been able to agree on what purpose interpretation is meant to serve. The majority of writers, diplomats and judges have been content to accept an apparently workable compromise, in the form of articles 31 and 32, and have been prepared also to assume that these impose a basically textual and hierarchical process on interpreters, albeit

290 Report of the International Law Commission on Draft Articles (1966) II YBILC 220, para 10, especially explicit reference to use of works to "confirm" a meaning. [ILC Commentary 1966] 
one which contains considerable flexibility, and scope to the individual interpreter. However, as different interpreters continue to hold quite different views about the basic purpose of what they are doing, it is hardly surprising they often arrive at quite different results. It has been submitted in this essay that this divergence of views remains unsatisfactory, and can lead courts and other interpreters to inappropriate and incoherent results. It is further argued that difficulties will persist, if the nettle which was not grasped by the ILC continues to be ignored.

It has been argued that contract law can point us in the right direction, to give appropriate prominence to the actual or objective intentions of treaty parties, wherever they can be discovered, thus accepting that discovering and giving effect to the will of the parties should be at the heart of treaty interpretation and treaty law. While it can and has been argued that such an approach is in fact consistent with and implicit in articles 31 and 32 themselves, it is evident that we need an appropriate stimulus to lead us to this necessary conclusion.

Whether such stimulus comes from contract insights, or from within international law itself, it is clear that interpretation will continue to be unpredictable, sometimes arbitrary, and often controversial, if this matter is not resolved. If articles 31 and 32 are to be more than devices in the hands of the interpreter who seeks to achieve a given or predetermined result, we must be prepared to answer the "purpose" question, in favour of the actual intentions of the parties. 